\title{
17. LATE PLEISTOCENE EVOLUTION OF SURFACE AND MID-DEPTH HYDROGRAPHY AT THE OMAN MARGIN: PLANKTONIC AND BENTHIC ISOTOPE RECORDS AT SITE 7241
}

\author{
Rainer Zahn ${ }^{2,3}$ and Thomas F. Pedersen ${ }^{2}$
}

\begin{abstract}
Stable isotope records of coexisting benthic foraminifers Uvigerina spp. and Cibicidoides spp. and planktonic G. ruber (white variety) from Site $\mathbf{7 2 4}$ are used to study the late Pleistocene evolution of surface and intermediate water hydrography ( $593 \mathrm{~m}$ water depth) at the Oman Margin. Glacial-interglacial $\delta^{18} \mathrm{O}$ amplitudes recorded by the benthic foraminifers are reduced when compared to the estimated mean ocean changes of $\delta^{18} \mathrm{O}_{\text {seawater. }}$. Epibenthic $\delta^{13} \mathrm{C}$ remains at its modern level or is increased during glacial times. This implies that Red Sea outflow waters which are enriched in $\delta^{18} \mathrm{O}_{\text {seawater }}$ and $\delta^{13} \mathrm{C}_{\Sigma \mathrm{EO}_{2}}$ have been replaced during glacial periods by intermediate waters still positive in $\delta^{13} \mathrm{C}_{\Sigma \mathrm{CO}_{2}}$ but more negative in $\delta^{18} \mathrm{O}_{\text {seawater }}$. Glacial-interglacial amplitudes of the planktonic $\delta^{18} \mathrm{O}$ record exceed those of the mean ocean $\delta^{18} \mathrm{O}_{\text {seawater }}$ variation and imply decreased surface water temperatures (SST) during glacial times. Throughout most of the records these cooling events correlate with enhanced rates of carbon accumulation. However, both negative (colder) SST and positive $\mathrm{C}_{\text {org }}$ accumulation rate anomalies do not correlate with potential physical upwelling maxima as inferred from the orbital monsoon index. This is in conflict with the established hypothesis that upwelling in the western Arabia Sea should be strongest during maxima of the southwest monsoon.
\end{abstract}

\section{INTRODUCTION}

The chemical structure of the world ocean has changed during the Pleistocene as a function of global climate. Benthic foraminiferal $\delta^{13} \mathrm{C}$ and $\mathrm{Cd} / \mathrm{Ca}$ records from pelagic core sites, for instance, point to lower ventilation rates and higher nutrient contents in the deep ocean during glacial episodes (Curry et al., 1985; Duplessy et al., 1988; Boyle, 1988a). In contrast, benthic ${ }^{13} \mathrm{C}$ and $\mathrm{Cd} / \mathrm{Ca}$ data from shallow core sites $(<1.5 \mathrm{~km}$ water depth) in the North Atlantic and North Pacific Oceans imply that mid-depth nutrient levels were lower during glacial times (Zahn et al., 1987; Curry et al., 1988; Duplessy et al., 1988; Boyle 1988b). This apparent contrast between mid-depth and deep ocean chemical cycling during glacial-interglacial times suggests that vertical fractionation processes in the ocean may play an important role in the global climate system (Boyle, 1988b). ODP Site 724 from a water depth of $593 \mathrm{~m}$ is well suited to study the long-term development of mid-depth hydrographic variations in the northern Indian Ocean. Also, its position under the Oman coastal upwelling regime makes it equally suitable for studying the evolution of monsoonal upwelling in the western Arabian Sea. In this paper we use records of benthic and planktonic foraminiferal stable isotopes and of organic carbon to decipher the evolution of coastal upwelling and intermediate depth hydrography at the Oman Margin.

\section{REGIONAL OCEANOGRAPHY}

Surface water circulation in the Arabian Sea is modulated by the seasonal variation of the monsoon wind system. In response to the southwest monsoon, strong upwelling occurs off the coasts of Oman and Somalia during the summer months (May through October) due to the wind-induced offshore Ekman transport. During this season the upwelling of cool waters leads to an enhanced heat loss in the Arabian Sea which results in a zonal

${ }^{1}$ Prell, W. L., Niitsuma, N., et al., 1991. Proc. ODP, Sci. Results, 117: College Station, TX (Ocean Drilling Program).

2 The University of British Columbia, Department of Oceanography, 6270 University Boulevard, Vancouver, B.C. V6T 1W5, Canada.

3 (Current address) Geomar, Wischhofstraße 1-3, Gebäude 4, D-230 Kiel-14, Federal Republic of Germany. temperature gradient of $>4^{\circ} \mathrm{C}$ between the upwelling center and the open ocean (Wyrtki, 1971; Düing and Leetmaa, 1980). At the same time the concentrations of all major nutrients (silicate, phosphate, nitrate) reach a maximum (Wyrtki, 1971) due to an injection of nutrients from below the thermocline into the surface waters. Carbon productivity reaches some $1.5 \mathrm{~g} \mathrm{~m}^{-2}$ day $^{-1}$ (Kabanova, 1968; Cushing, 1973; Krey, 1973) which, for example, is twice the productivity observed at the upwelling center off Northwest Africa $\left(0.7 \mathrm{~g} \mathrm{~m}^{-2}\right.$ day $^{-1}$; Schemainda et al., 1975). Advection of nutrient-rich upwelled water offshore from the Somali-Arabian upwelling center supports high production in surface waters more than $400 \mathrm{~km}$ from the continental margin (Nair et al., 1989). During the winter months (November through April) the prevailing northeast monsoon winds result in an onshore Ekman transport of surface waters which leads to a collapse of all upwelling activity along the continental margin of the Western Indian Ocean.

The high rate of input of organic matter and its subsequent oxidation below the thermocline is associated with a very high oxygen demand at intermediate depths. The resulting oxygen deficiency is fostered by the sluggish intermediate water circulation which partly results from the cul-de-sac-type geometry of the northern Arabian Sea (Wyrtki, 1973). In addition, the strong tropical-subtropical thermocline prevents downward mixing of oxygenated surface waters thus enhancing the effect of the low renewal rate of intermediate waters (Swallow et al., 1983). As a result of these factors, the oxygen minimum in the Northern Arabian Sea is one of the most severe encountered in the world ocean. Waters between 200 and $1500 \mathrm{~m}$ water depth are oxygendepleted to an extent that they contain on occasion free $\mathrm{H}_{2} \mathrm{~S}$ and are often relatively deficient in $\mathrm{NO}_{3}^{-}$(Qasim, 1982).

The intermediate-depth hydrography at the Oman continental margin is influenced by outflow waters from the Red Sea (Siedler, 1968; Düing and Schwill, 1968; Premchand et al., 1986a). Evaporation in the Red Sea by far exceeds fresh water supply and the outflow waters are considerably warmer and more saline than the adjacent ocean. Red Sea waters can therefore be easily recognized in the temperature-salinity (T-S) field as a mid-depth T-S maximum (Fig. 1). The volume transport between the Red Sea and the Arabian Sea is closely tied to the monsoonal cycle and may vary by a factor of five between the 


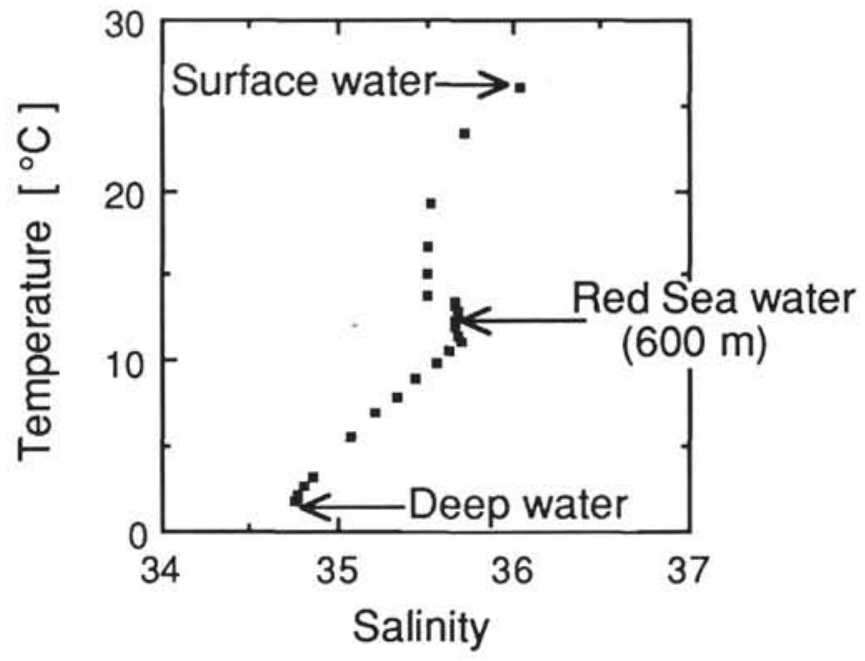

Figure 1. Temperature-salinity (T-S) field at Geosecs Station 413 in the western Arabian Sea. The core layer of the Red Sea outflow forms a well-defined T-S maximum at $600 \mathrm{~m}$.

summer and winter seasons (Souvermezoglou et al., 1989). Prevailing northeasterly winds strengthen the outflow during winter because of a positive mass balance which results from an enhanced wind-driven advection of surface waters from the Gulf of Aden into the Red Sea (Bethoux, 1987). In contrast, enhanced wind-driven outflow of surface waters during the southwest monsoon in summer decreases the deep outflow and forces a subsurface inflow to balance the mass deficiency (Bethoux, 1987). Red Sea outflow waters also considerably increase the nutrient levels at intermediate depths in the Arabian Sea through an estimated carbon export of $26 \times 10^{12} \mathrm{~mol} \mathrm{yr}^{-1}$ (Bethoux, 1988). Persian Gulf waters on the other hand spread in the Arabian Sea at depths shallower than $300 \mathrm{~m}$ (Düing and Schwill, 1968; Premchand et al., 1986b) and thus do not contribute to the intermediate depth waters at Site 724 .

\section{METHODS}

\section{Stable Isotopes}

Isotope analyses were run on a VG Isogas Prism mass spectrometer using an on-line VG Isogas Autocarb automated carbonate preparation device. Release and preparation of the carbon dioxide gas for isotope analysis follows the standard techniques described in Shackleton and Opdyke (1973) with the exception that reactions occur at $90^{\circ} \mathrm{C}$ in a common acid bath. That is, up to 40 sample reactions occur in the same reaction vessel containing $5 \mathrm{~cm}^{3}$ of $100 \%$ orthophosphoric acid. Potential memory effects are below $1 \%$ of the isotope offset between samples as revealed by sequential analysis of carbonates with an isotope offset of about $20 \% 0$ in $\delta^{18} \mathrm{O}$. Calibration of the mass spectrometer to the international PeeDee Belemnite (PDB) carbonate standard was done primarily using National Bureau of Standards (NBS) carbonate standards 19 and 20 . External precision of the system for $\delta^{18} \mathrm{O}$ and $\delta^{13} \mathrm{C}$ was better than $0.06 \% 0$ and $0.04 \%$, respectively ( $1 \sigma$ standard deviation, $\mathrm{n}=75$; determined from a replicate laboratory standard run with the samples over a 3-month period). As a further indication of precision, 6 replicate analyses each of 20 specimens of Neogloboquadrina pachyderma from the same sample taken from a high sedimentation rate core $\left(8 \mathrm{~cm} \mathrm{k.y.}{ }^{-1}\right)$ from the Northeast Pacific yielded a $1 \sigma$ standard deviation of $0.06 \%$ in both $\delta^{18} \mathrm{O}$ and $\delta^{13} \mathrm{C}$.
Stable isotope measurements were run for the upper $32 \mathrm{~m}$ of Core $724 \mathrm{C}$, which was sampled continuously at $20 \mathrm{~cm}$ intervals. Records were obtained from the planktonic foraminifer Globigerinoides ruber (white variety) and from the two benthic genera Cibicidoides spp. and Uvigerina spp. Identification of the benthic foraminifers on the species level follows the nomenclature given in Resig (1981) and Lutze (1986). Accordingly, measurements were run on Uvigerina auberiana d'Orbigny, Uvigerina senticosa Cushman, Cibicidoides wuellerstorfi (Schwager), and Cibicides mundulus (Brady, Parker and Jones). The isotope samples contained on average 25 planktonic and 5-7 benthic specimens which were picked from the size fractions 300-355 $\mu \mathrm{m}$ and 250-355 $\mu \mathrm{m}$, respectively. All samples were mechanically crushed, ultrasonically rinsed in methanol, and roasted in vacuo for $30 \mathrm{~min}$ at $430^{\circ} \mathrm{C}$. This cleaning procedure was applied so as to release occluded fine-grained carbonate particles and to remove impurities and organic coatings from the tests which could alter the isotope values. All isotope data are listed in Appendix $\mathbf{A}$.

\section{Organic Carbon}

Organic carbon $\left(\mathrm{C}_{\text {org }}\right)$ was determined as the difference between total carbon measurements made by combustion and thermal conductivity detection of $\mathrm{CO}_{2}$ using a Carlo-Erba NA 1500 CNS analyzer ( $1 \sigma$ relative standard deviation is better than $2 \%$ ), and carbonate carbon measurements made by acidification with hot $20 \% \mathrm{HCl}$ and coulometric quantification of the evolved $\mathrm{CO}_{2}$ using a Coulometrics analyzer. All carbonate carbon measurements were made in duplicate and the mean used to increase the precision of the $\mathrm{C}_{\text {org }}$ (by difference) data. The $1 \sigma$ relative standard deviation of the carbonate carbon analyses was $1 \%$. The $\mathrm{C}_{\text {org }}$ data presented in this paper are considered precise to within $\pm 3 \%(1 \sigma)$. All $\mathrm{C}_{\text {org }}$ data are listed in Appendix B.

\section{RESULTS}

\section{Oxygen Isotope Stratigraphy}

The isotope record obtained from Cibicidoides spp. is incomplete and shows relatively large scatter (Fig. 2) reflecting the low abundance of this genus in the sediment samples. Whereas the low number of specimens (1-3) available for some measurements may seriously lower the reliability of the Cibicidoides spp. isotope record, this problem is of minor importance for the Uvigerina spp. record (Fig. 2) which was measured on samples generally containing 5-10 specimens. Since we will use the interspecific $\delta^{13} \mathrm{C}$ difference between Uvigerina spp. and Cibicidoides spp. later as a proxy for the potential gradient of pore-water $\delta^{13} \mathrm{C}_{\Sigma \mathrm{CO}_{2}}$, it is especially important to check for the reliability of the Cibicidoides spp. isotope data. We have done this by using the statistically better constrained Uvigerina spp. record as a reference. All Cibicidoides spp. data which deviate by more than $0.2 \%$ from the generally accepted $\delta^{18} \mathrm{O}$ difference of $0.64 \%$ between both genera (Shackleton and Opdyke, 1973) have been discarded from the record (Fig. 3). Accordingly, 63 out of a total of 113 Cibicidoides spp. data have been rejected. The glacial core sections were most severely affected by this rigorous cut-off process. However, in view of the importance of the data for our later discussion, this "clean-out" appears thoroughly appropriate.

The $\delta^{18} \mathrm{O}$ records obtained from $G$. ruber and from $U v i g e r-$ ina spp. (Fig. 2) display distinct $\delta^{18} \mathrm{O}$ maxima at sub-bottom depths of $2 \mathrm{~m}, 7 \mathrm{~m}, 12 \mathrm{~m}$, between $23 \mathrm{~m}$ and $25 \mathrm{~m}$, and at $30 \mathrm{~m}$. We interpret these maxima as documenting glacial oxygen isotope stages $2,4,6,8$, and 10 . In addition, we used the $\delta^{18} \mathrm{O}$ minimum of $G$. ruber at $9.4 \mathrm{~m}$ as the stratigraphic fix point for the last interglacial substage $5 \mathrm{e}$. No control points were used for the 

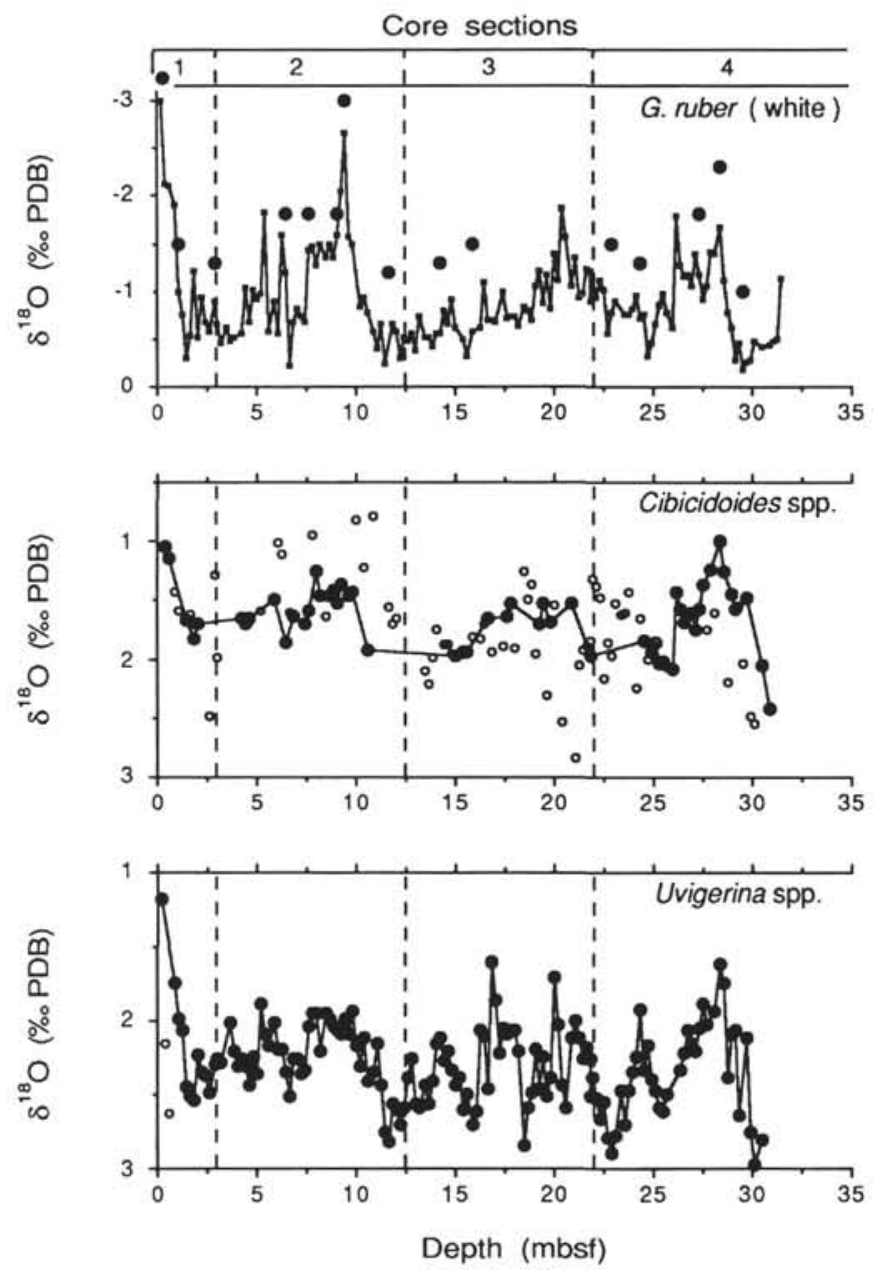

Figure 2. Oxygen isotope records of planktonic foraminifer $G$. ruber (white variety) and of benthic foraminifers Uvigerina spp. and Cibicidoides spp. Open symbols are rejected data (see Fig. 3). The data gaps in the Cibicidoides spp. record are caused by the discontinuous occurrence of this genus (see also Fig. 5). Full dots in the G. ruber isotope record mark the position of the stratigraphic fix points which were used for developing the time model for Site 724. The age control points are listed in Table 1. All isotope data are listed in Appendix A.

broad $\delta^{18} \mathrm{O}$ minimum between 16 and $23 \mathrm{~m}$. We believe that this minimum correlates with interglacial oxygen isotope stage 7 , but the structure of the benthic and planktonic $\delta^{18} \mathrm{O}$ profiles in this core section is inconclusive and does not allow for more detailed stratigraphic correlation to the Specmap $\delta^{18} \mathrm{O}$ stack (Imbrie et al., 1984) which was used as a reference. Magnetic susceptibility data at Site 724 show a good correlation among holes $\mathrm{A}, \mathrm{B}$, and $\mathrm{C}$ implying that there are no major gaps or overlaps between sub-cores 1 through 4 (Peter deMenocal, written comm., 1988), and that the sediment sequence, and thus also the isotope record, of Hole $724 \mathrm{C}$ is complete.

The stratigraphic fix points which were used to develop the age model for Hole $724 \mathrm{C}$ have been picked by employing the corresponding age control points from the Specmap global stack of $\delta^{18} \mathrm{O}$ (Imbrie et al., 1984) (see Table 1). Accordingly, the upper $32 \mathrm{~m}$ of Hole $724 \mathrm{C}$ spans the past $350,000 \mathrm{yr}$ (Fig. 4) which implies mean sedimentation rates of about $9 \mathrm{~cm} \mathrm{k.y.}{ }^{-1}$. Linear interpolation between the depth position of the oxygen isotope stage boundaries reveals downcore variations of sedimentation rates between maximum values of $15 \mathrm{~cm} \mathrm{k.y.}{ }^{-1}$ (oxygen isotope

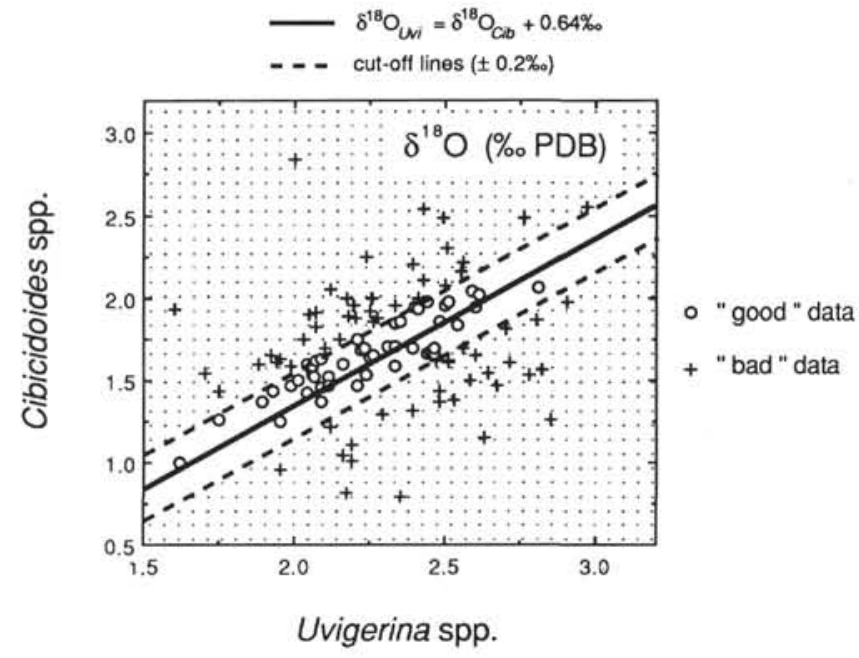

Figure 3. Uvigerina spp. vs. Cibicidoides spp. comparison of $\delta^{18} \mathrm{O}$. All Cibicidoides spp. data which deviate by more than $\pm 0.2 \% 0$ from the accepted $\delta^{18} \mathrm{O}$ difference of $0.64 \%$ between both genera were discarded from the isotope record.

Table 1. Age control points used to develop the time model for Hole 724C.

\begin{tabular}{crr}
\hline $\begin{array}{c}\text { Sub-bottom } \\
\text { depth }(\mathrm{m})\end{array}$ & $\begin{array}{c}\text { Age } \\
(\mathrm{k} . \mathrm{y} . \mathrm{BP})\end{array}$ & $\begin{array}{r}\text { Specmap } \\
\text { event }^{\mathrm{a}}\end{array}$ \\
\hline 0.22 & 6.0 & 1.1 \\
1.10 & 12.0 & 2.0 \\
2.90 & 24.0 & 3.0 \\
6.42 & 59.0 & 4.0 \\
7.62 & 71.0 & 5.0 \\
9.02 & 110.0 & 5.4 \\
9.42 & 122.0 & 5.5 \\
11.62 & 135.0 & 6.2 \\
14.22 & 171.0 & 6.5 \\
15.82 & 183.0 & 6.6 \\
22.92 & 249.0 & 8.2 \\
24.32 & 287.0 & 8.5 \\
27.32 & 320.0 & 9.2 \\
28.32 & 331.0 & 9.3 \\
29.52 & 341.0 & 10.2 \\
\hline
\end{tabular}

${ }^{a}$ From Imbrie et al. (1984).

stages 1 and 2) and minimum values of $3.5 \mathrm{~cm} \mathrm{k.y.}{ }^{-1}$ (oxygen isotope stage 5) (Fig. 5). Apparently, there is no systematic correlation between variation of sedimentation rates and the state of glacial-interglacial climates, which hints that additional processes such as sediment focusing and winnowing may be superimposed on the climatically-controlled variations of eolian sediment input and changes of biological productivity. Time resolution of the isotope records at a sample interval of $20 \mathrm{~cm}$ varies between $3 \mathrm{k} . \mathrm{y}$. and $11 \mathrm{k} . \mathrm{y}$. as a function of sedimentation rate (calculated as Nyquist period: $2 \times$ [sample interval/sedimentation rate]; Balsam and Posmenier, 1981).

Comparison with standard isotope profiles such as the benthic $\delta^{18} \mathrm{O}$ record of equatorial Pacific core V19-30 (Shackleton and Pisias, 1985) shows that the glacial-interglacial $\delta^{18} \mathrm{O}$ amplitudes at Site 724 are often reduced (Fig. 4). This effect is most prominent in the benthic $\delta^{18} \mathrm{O}$ record. In addition, interglacial stage 7 is not well resolved in our records. These irregularities have been confirmed by more than 40 re-runs of foraminiferal samples from the respective core sections and we can therefore exclude analytical errors as a cause for the deviations of our iso- 

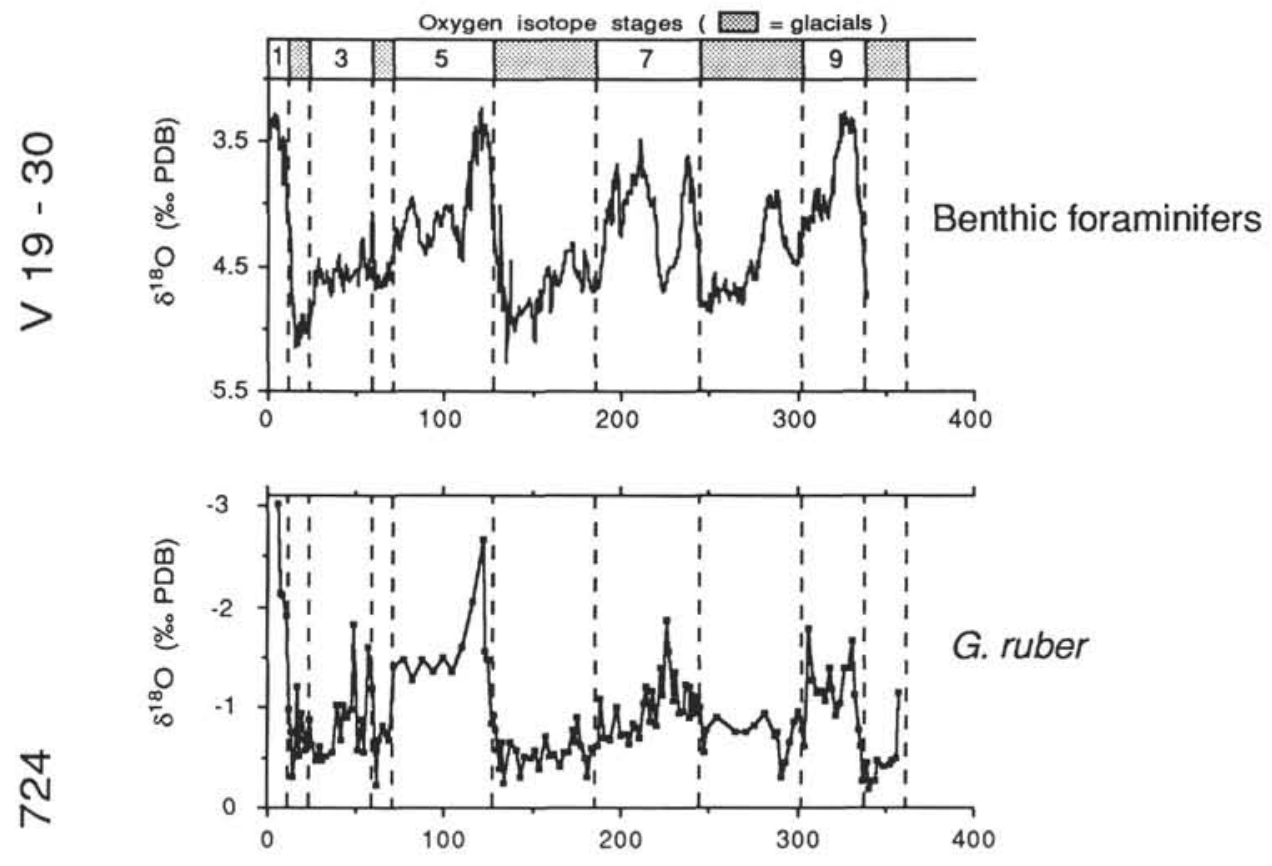

$\stackrel{\oplus}{\oplus}$

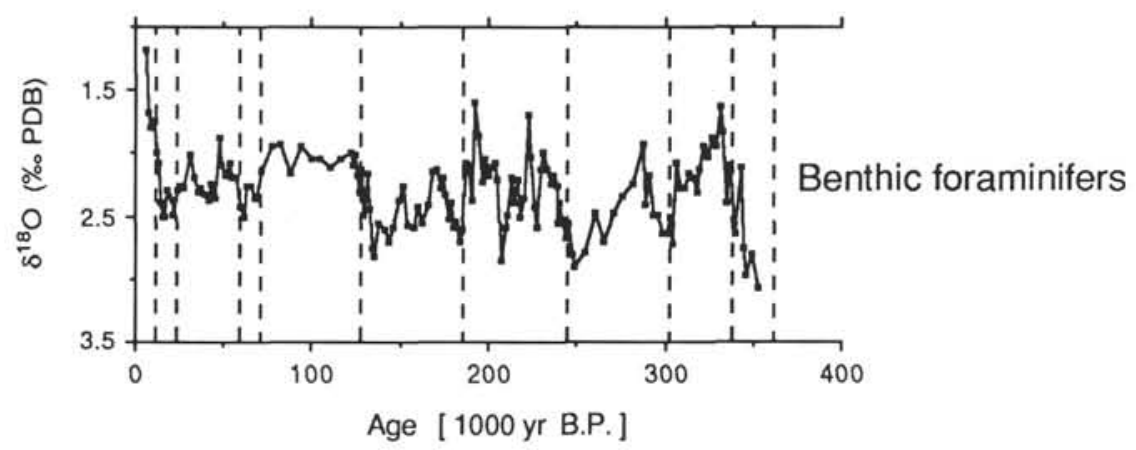

Figure 4. The benthic and planktonic $\delta^{18} \mathrm{O}$ records in the time domain. The benthic record includes $U v i-$ gerina spp. and Cibicidoides spp. data. The Cibicidoides spp. $\delta^{18} \mathrm{O}$ data were converted to the Uvigerina scale of $\delta^{18} \mathrm{O}$ by adding $0.64 \%$. Comparison with the pelagic benthic $\delta^{18} \mathrm{O}$ record of equatorial Pacific core V19-30 $\left(3^{\circ} \mathrm{S}, 83^{\circ} \mathrm{W}, 3091 \mathrm{~m}\right.$; Shackleton and Pisias, 1985) shows that the glacial-interglacial $\delta^{18} \mathrm{O}$ amplitudes at Site 724 are considerably lower than those observed in the deep ocean. This effect is most prominent in the benthic $\delta^{18} \mathrm{O}$ record and points to systematic $\delta^{18} \mathrm{O}_{\text {seawater }}$ changes of the intermediate depth waters at Site 724 .

tope records from standard deep-sea isotope profiles. As noted above, magnetic susceptibility data do not indicate major gaps or overlaps between the core sections, which excludes this source of potential stratigraphical disturbance. The magnitude of foraminiferal $\delta^{18} \mathrm{O}$ variation through time is determined by variations of global ice volumes and by local variations of $\delta^{18} \mathrm{O}_{\text {seawater }}$ and water temperature. In view of the high sedimentation rates (see above), an influence of vertical mixing by burrowing organisms of foraminiferal shells across stratigraphic boundaries, which has the potential to considerably reduce the $\delta^{18} \mathrm{O}$ variance of the downcore records, may be of minor importance at Site 724. The quasi-coherent variation of the benthic and planktonic $\delta^{18} \mathrm{O}$ curves in Hole $724 \mathrm{C}$ (Fig. 4) implies that both records contain the global ice volume effect. That is, the irregular structures of the $\delta^{18} \mathrm{O}$ profiles are likely the result of variations of the ambient water hydrography at Site 724 or of downslope migration of foraminiferal shells winnowed by local undercurrents and tidal flow regimes from shallower upper slope or shelf sediments.

Changes in the absolute abundance of foraminiferal species used for isotope measurements may significantly enhance arti- facts introduced by bioturbation and lead to vertical translations of the isotope signals (Berger and Heath, 1968; see also discussion by Climap Project Members, 1984). To evaluate the potential influence that such effects may have had on the isotope records at Site 724 we have checked for the abundance distribution of Uvigerina spp. and Cibicidoides spp. during the last two climatic cycles, i.e., back to oxygen isotope stage 8 . Specimen abundances of both genera were determined for the same size fraction from which the benthic isotope samples were picked (i.e., 250-355 $\mu \mathrm{m}$ ). As Figure 6 shows, Uvigerina spp. are by far more abundant in the sediment samples than Cibicidoides spp. Massive incursions of Uvigerina spp. specimens are observed during mid-stage 7 , late stage 6 , and during early stage 3 (Fig. 6). Cibicidoides spp. maxima occur during stage 7 and early stage 6 , in late stage 4 , and mid-stage 3 (Fig. 6). The most dominant abundance maximum occurs synchronously for both genera during mid-stage 3 . However, abundances of both genera do not significantly change across the stratigraphic boundary between full glacial isotope stage 6 and full interglacial isotope substage 5e (Fig. 6). The Uvigerina spp. maximum at 145 k.y. 


\section{Sedimentation rates}

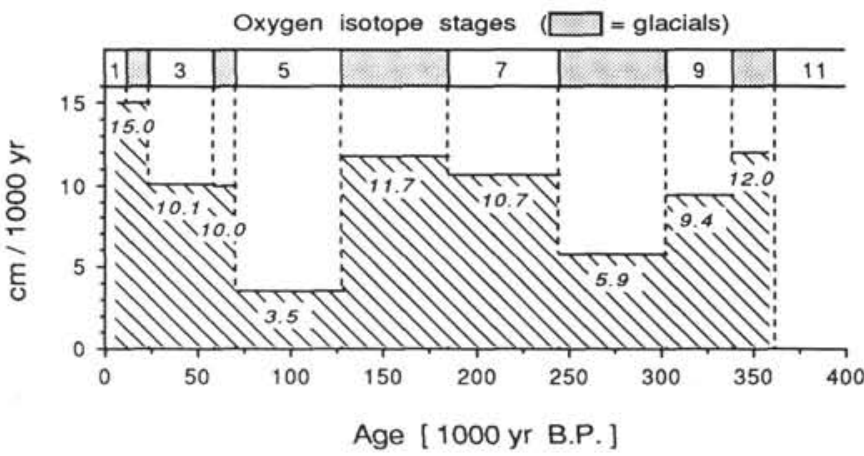

Figure 5 . Sedimentation rates at Site 724 calculated by linear interpolation between the depth positions of oxygen isotope stage boundaries as implied by the time model. Time resolution of the isotope records was calculated as a function of sampling interval $(20 \mathrm{~cm})$ and sedimentation rate, and varies between 3 k.y. (isotope stages 1 and 2) and 11 k.y. (isotope stage 5).

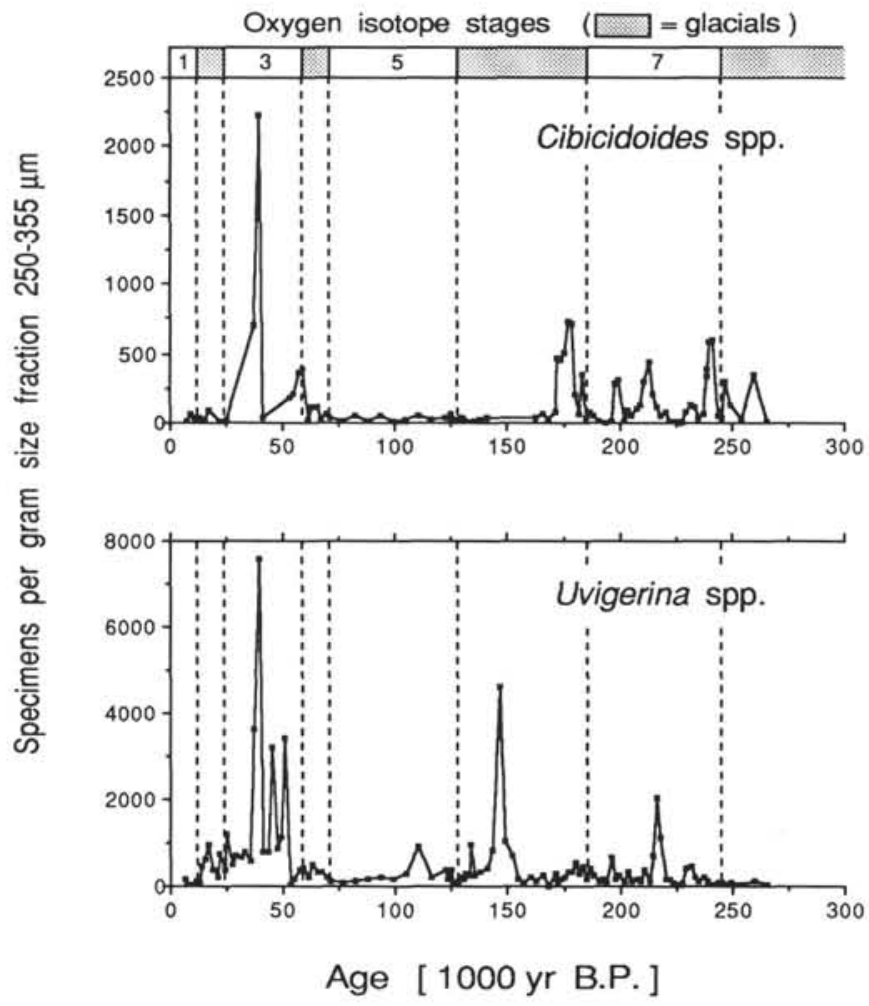

Figure 6. Abundance of Cibicidoides spp. and Uvigerina spp. at Site 724 during the past $270,000 \mathrm{yr}$. The abundance record is used to evaluate the potential effect on the glacial-interglacial benthic $\delta^{18} \mathrm{O}$ amplitudes of bioturbational admixture of foraminiferal shells across the stratigraphic boundaries. Apparently no major change in abundance occurs at the oxygen isotope stage boundary $5 / 6$. The concurrently reduced $\delta^{18} \mathrm{O}$ amplitude may therefore document a change of the oxygen isotope composition of intermediate waters at the Oman Margin.
B.P. ( $>4600$ specimens per gram of size fraction $250-355 \mu \mathrm{m}$ ) is about $3 \mathrm{~m}$ below the core section where depleted $\delta^{18} \mathrm{O}$ values of $G$. ruber indicate the last interglacial 5e. Therefore, reduction in amplitude of the isotope records is not likely to be the result of bioturbation. Based on the evidence to date we conclude that the depletion of the glacial-interglacial $\delta^{18} \mathrm{O}$ amplitudes at Site 724 points to systematic variations in temperature and the $\delta^{18} \mathrm{O}_{\text {seawater }}$ of surface and intermediate waters in the Western Arabian Sea. The implications of this are discussed below.

\section{Carbon Isotope Records}

Comparison of the benthic and planktonic $\delta^{13} \mathrm{C}$ records with mean ocean variations of $\delta^{13} \mathrm{C}$ is again obtained by using the isotope record from core V19-30 (Shackleton and Pisias, 1985) (Fig. 7). Both the G. ruber and Uvigerina spp. records at Site 724 show depleted $\delta^{13} \mathrm{C}$ values during glacial times, and the carbon isotope profiles are in this respect coherent with those of equatorial Pacific core V19-30. Mismatches between the carbon isotope profiles at Site 724 and core V19-30 occur during late stage 7 . Our $\delta^{18} \mathrm{O}$ records from this section correlate rather poorly with the global $\delta^{18} \mathrm{O}$ stratigraphy (see above), and the intercore $\delta^{13} \mathrm{C}$ differences shown in Figure 7 could be due to inaccuracies in our chronostratigraphy. $\delta^{13} \mathrm{C}$ variations of Cibicidoides spp. at Site 724 appear to be decoupled from the variations observed in the $\delta^{13} \mathrm{C}$ record of coexisting Uvigerina spp. specimens (Fig. 7). Because of its presumed epibenthic microhabitat (Corliss, 1985; Lutze and Thiel, 1987), Cibicidoides spp. are considered to record faithfully $\delta^{13} \mathrm{C}$ changes of ambient bottom water $\mathrm{\Sigma CO}_{2}$ (Curry et al., 1988, and references therein). $\delta^{13} \mathrm{C}$ fluctuations of Uvigerina spp. on the other hand appear to reflect carbon isotope variations of pore water $\mathrm{\Sigma CO}_{2}$ because of the presumed endobenthic habitat of this genus (Zahn et al., 1986; McCorkle et al., 1989). That is, the apparently incoherent variation of $\delta^{13} \mathrm{C}$ for coexistent Cibicidoides spp. and Uvigerina spp. at Site $\mathbf{7 2 4}$ may be viewed as documenting largely independent variations of $\delta^{13} \mathrm{C}_{\mathrm{ECO}_{2}}$ in the ambient bottom waters and in the pore water, the latter being closely related to variations of the organic carbon flux into the sediments (McCorkle et al., 1985) and thus to productivity changes in the surface waters (Zahn et al., 1986).

\section{Organic Carbon Variations}

The organic carbon profile at Site 724 shows values between 0.5 and $2.0 \mathrm{wt} \%$ (Fig. 8A) with the exception of a sharp maximum in mid-stage 3 where the concentration reaches nearly $4 \%$. This value has been confirmed by repeat measurements. Apparently the downcore carbon contents do not vary systematically as a function of glacial-interglacial climates in that carbon contents are high both during interglacial and glacial oxygen isotope stages (Fig. 8A).

In order to interpret properly variations of organic carbon through time in terms of paleoproductivity changes we have to convert the profile of organic carbon content ( $w t \%)$ into a profile of carbon accumulation rate $\left(\mathrm{mg} \mathrm{cm}^{-2} 1000 \mathrm{yr}^{-1}\right)$ which takes into account changes in sediment porosity and sedimentation rate. This conversion was done by multiplying the organic carbon data with the mean sedimentation rates shown in Figure 5 and the shipboard density data obtained by the Gamma Ray Attenuation Porosity Evaluator (GRAPE) (Fig. 8B). The GRAPE wet-bulk-density analog data were converted into dry-bulk-density data using the empirically determined regression equation

$$
\begin{aligned}
\text { Density }_{(\text {dry })}= & 1.585 \times \text { density }_{(\text {GRAPE })}-1.692 \\
& \left(\mathrm{r}^{2}=0.64, \mathrm{n}=13\right)
\end{aligned}
$$

which was established by using 13 measured in-situ dry-bulkdensity data from the upper $40 \mathrm{~m}$ of Hole $724 \mathrm{C}$ as a reference. Equation 1 reproduces the in-situ control data to within 

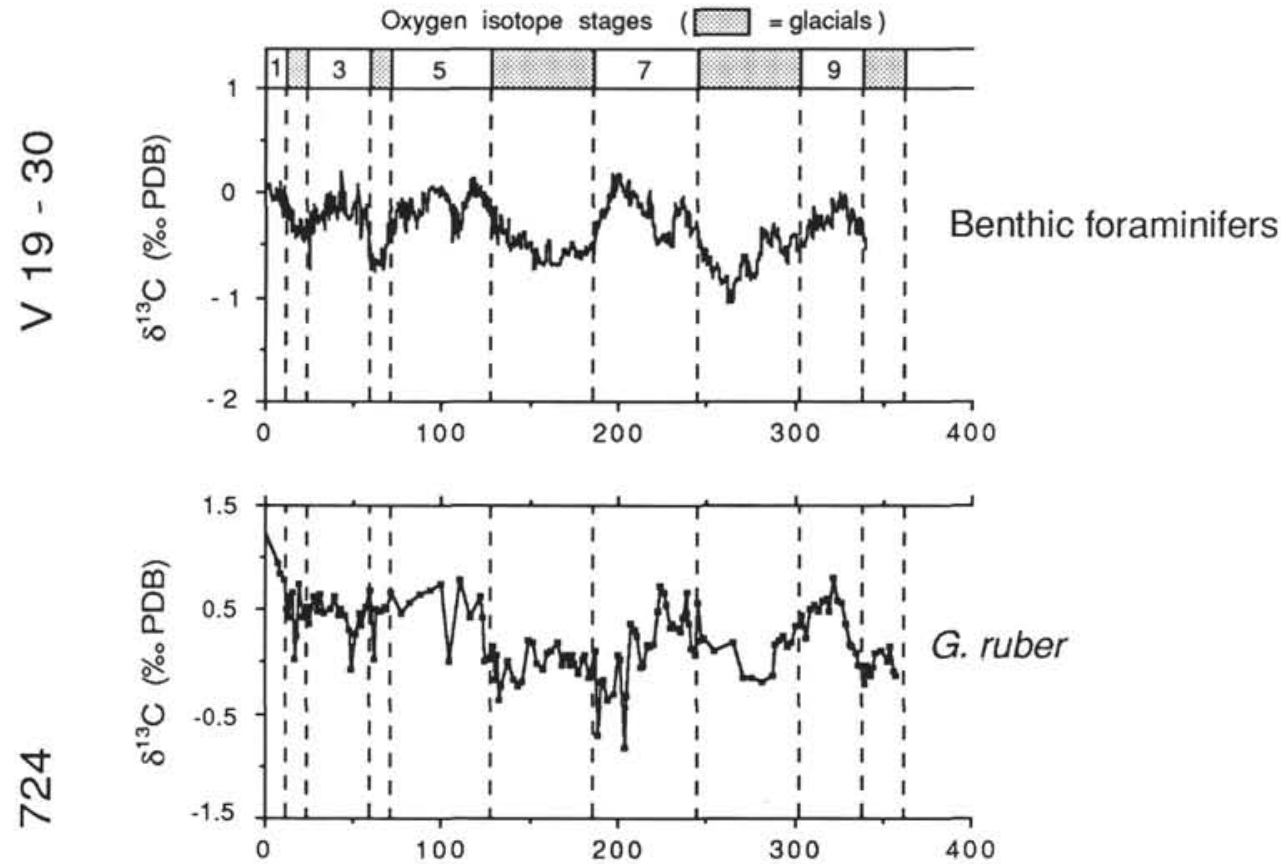

$\stackrel{0}{\oplus}$

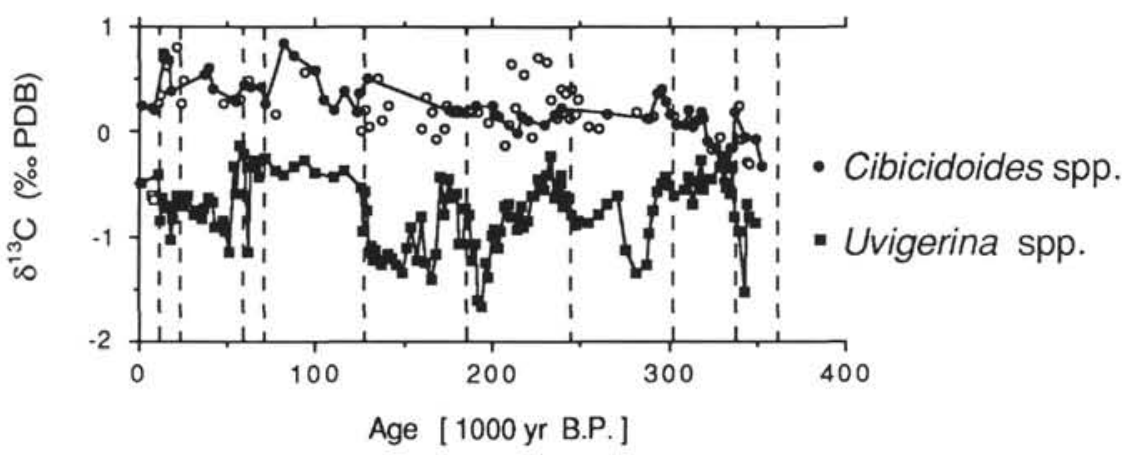

Figure 7. Benthic and planktonic $\delta^{13} \mathrm{C}$ variations at Site 724 during the past $350,000 \mathrm{yr}$. Open symbols are rejected data (see text). The benthic $\delta^{13} \mathrm{C}$ record of equatorial Pacific core V19-30 is from Shackleton and Pisias (1985) and is used here as a reference for deep-ocean $\delta^{13} \mathrm{C}_{\mathrm{\Sigma CO}_{2}}$ variations. $\delta^{13} \mathrm{C}$ variations of $G$. ruber and of Uvigerina spp. correlate well with those observed at core V19-30. In contrast, $\delta^{13} \mathrm{C}$ variations of epibenthic Cibicidoides spp. are apparently decoupled from those recorded by coexisting Uvigerina spp., pointing to the importance of $\delta^{13} \mathrm{C}_{\mathrm{ECO}_{2}}$ gradients between pore waters and ambient intermediate waters at Site 724 .

$\pm 0.1 \mathrm{~g} \mathrm{~cm}^{-3}$ ( $1 \sigma$ standard error). The GRAPE density analog data decrease sharply at the pipe breaks between sections 2 and 3 , and 3 and 4 (Fig. 8B) probably due to sediment flow-out. In both cases the last undisturbed value from the respective upper sections has been used to calculate the carbon accumulation rates (see also Appendix B). Likewise, no GRAPE data were available for Section $728 \mathrm{C}-4 \mathrm{H}-4$ and here the last density value from Section $728 \mathrm{C}-4 \mathrm{H}-3$ has been used.

As is the case with the $\% \mathrm{C}_{\text {org }}$ profile, organic carbon accumulation rates do not appear to be systematically linked to the state of global climate (Fig. 8C). For instance, broad carbon accumulation minima occur during oxygen isotope interglacial stage 5 and glacial stage 8 whereas maxima are documented during interglacial stages 7 and 9, and glacial stage 6 (Fig. 8C). As downcore variations of density are comparatively small (Fig. $8 \mathrm{~B})$, the reduction of the organic carbon signal in the accumulation record when compared to the percent profile during stages 5 and 8 are mostly controlled by sedimentation rate minima (see Fig. 5). Due to irregularities of our oxygen isotope records (see above) the implied chronostratigraphies, and thus the inferred sedimentation rate changes, are not tightly constrained. However, it appears unlikely that improvements of the chronostratigraphy will significantly alter the magnitude of the sedimentation rate variations and we believe that the structure of the organic carbon accumulation profile (Fig. $8 \mathrm{C}$ ) can be viewed as reasonably documenting the late Quaternary carbon burial rates at the upper Oman continental margin.

\section{DISCUSSION}

\section{The Planktonic Isotope Record of Changing SST and Upwelling}

Intense upwelling of cold and nutrient-enriched subsurface water causes significant gradients of temperature and nutrient levels in the surface ocean. Various studies have demonstrated that these upwelling signals are preserved in the $\delta^{18} \mathrm{O}$ and, at least to some extent, also in the $\delta^{13} \mathrm{C}$ values of planktonic foraminifers which have been exposed to the upwelled waters (e.g., 

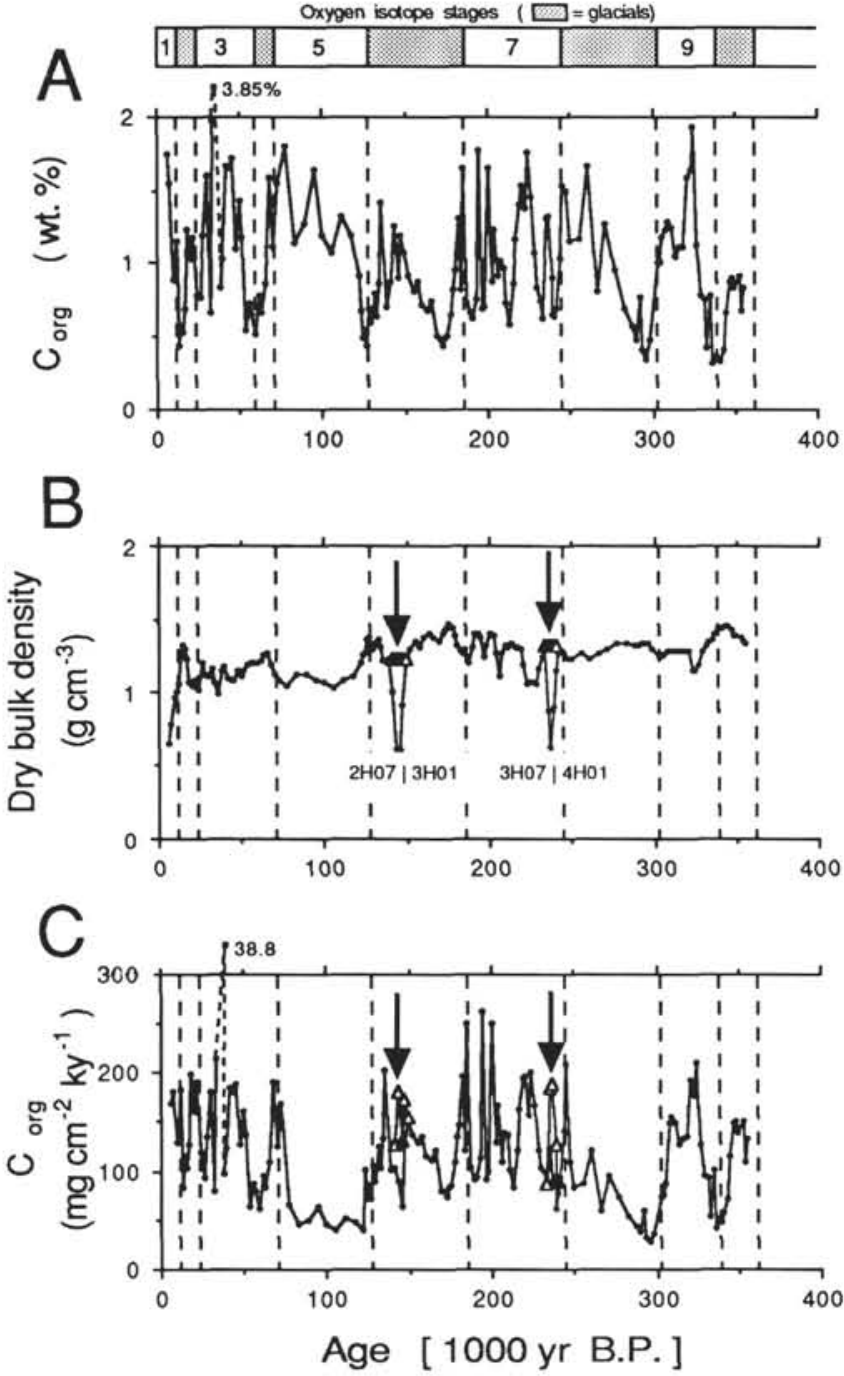

Figure 8. Organic carbon profile for Site 724 . A. wt $\%$ profile. B. GRAPE wet-bulk-density analog data, corrected to dry-bulk-density. C. Carbon accumulation rates. Percent-to-accumulation rate conversion procedure is described in the text.

Berger et al., 1978; Prell and Curry, 1981; Duplessy, 1982; Ganssen and Sarnthein, 1983; Kroon and Ganssen, 1989). The distinct susceptibility of the foraminiferal isotope composition to upwelling processes is determined by the fractionation response of $\delta^{18} \mathrm{O}$ and $\delta^{13} \mathrm{C}$ to varying temperature and nutrient cycling. Prell and Curry (1981) and Duplessy (1982) studied the stable isotope variation of planktonic foraminifera in core top samples from the Western Arabian Sea and found good correlations between upwelling-induced gradients of seasonal sea surface temperatures (SST) and the $\delta^{18} \mathrm{O}$ signal of shallow-dwelling planktonic foraminifers ( $G$. bulloides and $G$. ruber). In contrast, planktonic $\delta^{13} \mathrm{C}$ apparently does not correlate well with the upwelling-induced nutrient gradient (Prell and Curry, 1981). That is, planktonic $\delta^{18} \mathrm{O}$ appears to be a far better recorder of upwelling in the Arabian Sea than planktonic $\delta^{13} \mathrm{C}$.

In an attempt to extract the potential SST signal from the planktonic isotope record of Hole $724 \mathrm{C}$, we have estimated the difference of the $\delta^{18} \mathrm{O}$ variations of $G$. ruber from the mean ocean $\delta^{18} \mathrm{O}_{\text {seawater }}$ variations. To do this we have constructed a synthetic $\delta^{18} \mathrm{O}_{\text {seawater }}$ record for the past 350,000 yr by adjusting the amplitude of $\delta^{18} \mathrm{O}$ variations of the Specmap isotope stack
(Imbrie et al., 1984) (Fig. 9A) to those of the mean ocean $\delta^{18} \mathrm{O}_{\text {seawater }}$ curve of the past $120,000 \mathrm{yr}$ which was presented by Labeyrie et al. (1987) (Fig. 9B). At least $30 \%$ of the variation of foraminiferal $\delta^{18} \mathrm{O}$ on a glacial-to-interglacial time scale is due to changes of seawater temperature. The synthetic $\delta^{18} \mathrm{O}_{\text {seawater }}$ record shown in Figure $9 \mathrm{C}$ does not contain this temperature signal and hence, the range of variation in this record is significantly reduced. The interglacial $\delta^{18} \mathrm{O}$ level of the converted Specmap record (Fig. 9C) was then set to $-1.5 \%$ (PDB). This is the modern $\delta^{18} \mathrm{O}$ value of $G$. ruber in the Oman upwelling area as implied by core top values at shallow "inshore" sites ORKS 08 $(-1.58 \%$ (PDB), in Duplessy, 1982) and A15597 (-1.5\% (PDB), in Prell and Curry, 1981). This mean isotope record (bold line in Fig. 10A) should now represent the $\delta^{18} \mathrm{O}$ fluctuations of $G$. ruber solely as a function of mean ocean $\delta^{18} \mathrm{O}_{\text {seawater }}$ variations, i.e., as a function of ice volume changes. The synthetic record can therefore be considered to depict the expected variations in planktonic $\delta^{18} \mathrm{O}$ if no SST changes had occurred at Site 724 . Thus, deviations of the $G$. ruber $\delta^{18} \mathrm{O}$ profile from this synthetic record should represent the temperature signal included in the planktonic $\delta^{18} \mathrm{O}$ record. The isotope difference be-
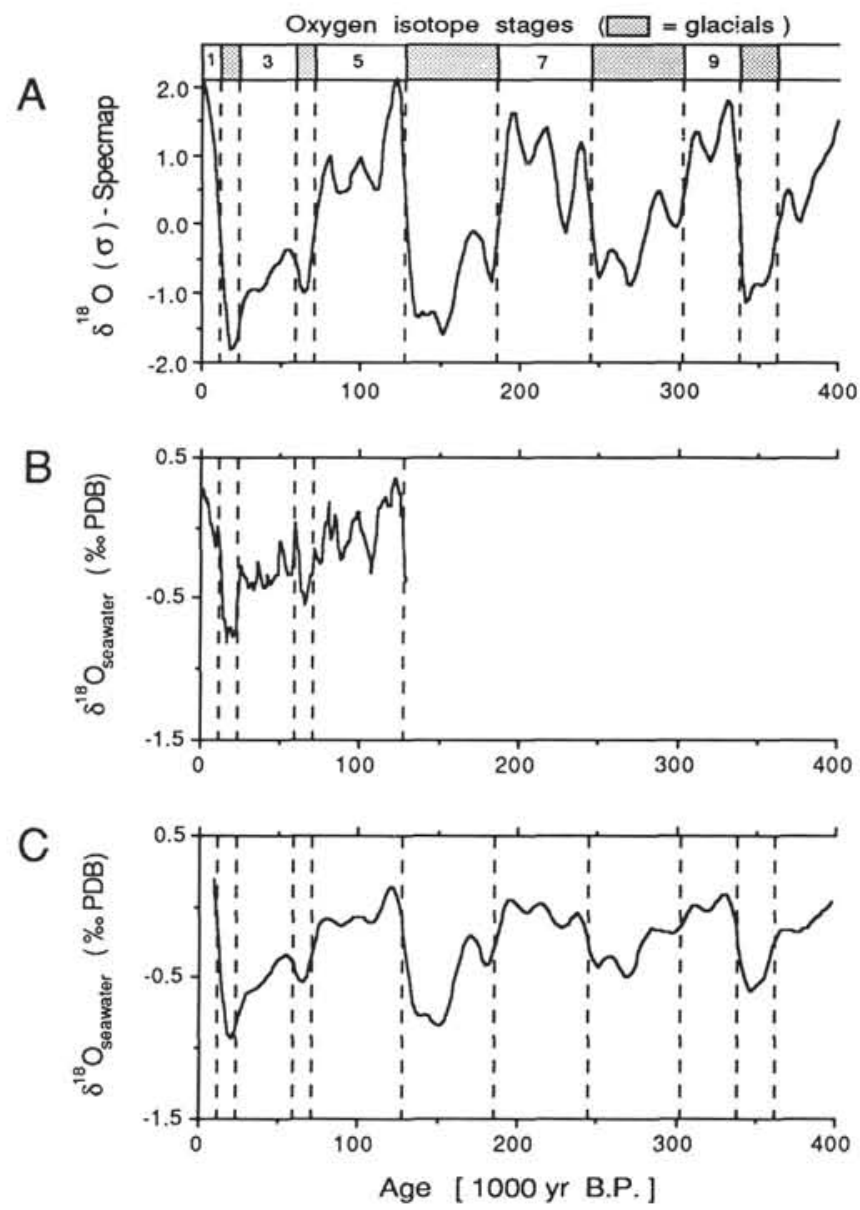

Figure 9. A. Specmap global stack of $\delta^{18} \mathrm{O}$ (from Imbrie et al., 1984). This record has been used to construct a $\delta^{18} \mathrm{O}_{\text {seawater }}$ record for the past 350,000 yr. B. Mean-ocean $\delta^{18} \mathrm{O}_{\text {seawater }}$ record as given in Labeyrie et al. (1987). C. Synthetic $\delta^{18} \mathrm{O}_{\text {seawater }}$ record constructed by adjusting the Specmap $\delta^{18} \mathrm{O}$ record to the $\delta^{18} \mathrm{O}_{\text {seawater }}$ record shown in B. This synthetic record was used as a reference to estimate possible SST and $\delta^{18} \mathrm{O}_{\text {seawater }}$ variations from glacial-interglacial fluctuations of planktonic and benthic $\delta^{18} \mathrm{O}$ at Site 724 . 

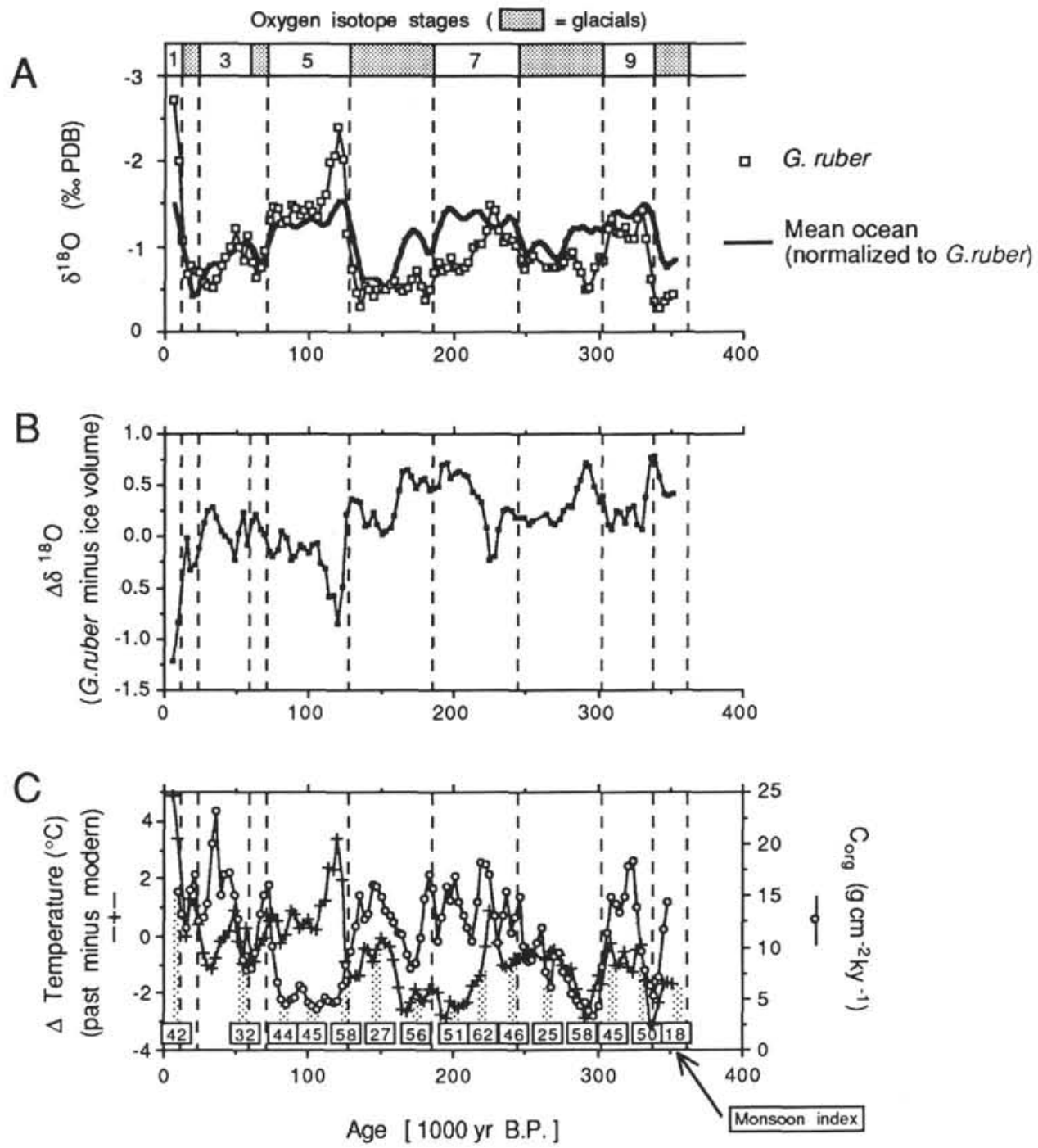

Figure 10. A. Comparison of surface water $\delta^{18} \mathrm{O}_{\text {calcite }}$ variations as recorded by $G$. ruber with mean-ocean $\delta^{18} \mathrm{O}$ seawater variations (heavy line). The original $G$. ruber $\delta^{18} \mathrm{O}$ record has been smoothed by a $12 \mathrm{k} . \mathrm{y}$. Gaussian filter at a step size of $3 \mathrm{k} . \mathrm{y}$. The mean-ocean $\delta^{18} \mathrm{O}_{\text {seawater }}$ record is the same as in Figure $9 \mathrm{C}$ with the exception that its interglacial isotope level is adjusted to $-1.5 \%$ which is the modern $\delta^{18} \mathrm{O}$ value of $G$. ruber at the coast of Oman (see text). B. $\delta^{18} \mathrm{O}$ difference between the mean-ocean record (normalized to $G$. ruber and the $G$. ruber isotope record. C. Temperature deviation from the modern SST as estimated from the isotope difference (crosses) and variation of organic carbon accumulation (open circles). Also shown are maxima of the orbital monsoon index which may be used as an indicator for potential upwelling intensity. For discussion see text.

tween the measured and synthesized profiles was calculated by sampling both records at 3 k.y. intervals and subtracting them from each other (Fig. 10B). Finally, the isotope difference was transformed into temperature by assuming a mean fractionation response of $\delta^{18} \mathrm{O}_{\text {calcite }}$ of $0.25 \%$ per $1^{\circ} \mathrm{C}$ temperature change. The resulting temperature record (crosses in Fig. 10C) therefore gives temperature as degree centigrade deviation from the modern SST.

The magnitude of the SST deviations from the modern would have been much larger (i.e., $\Delta \mathrm{SST} \geq 8^{\circ} \mathrm{C}$ ) had we chosen the more negative $\delta^{18} \mathrm{O}$ value of $-2.7 \%$ (PDB) as the modern control for the $G$. ruber isotope record. This value has been obtained by Kroon and Ganssen (1989) from living specimens collected in plankton tows at $12^{\circ} \mathrm{N}$ (plankton tow stations 112 and 118; Kroon and Ganssen, 1989). However, we believe that this negative value records the warm nonupwelling SST typical for tropical-subtropical surface waters and is not representative of the cold upwelled waters extant at Site 724.

Strongly negative deviations of as much as $1 \% 0$ from the modern $\delta^{18} \mathrm{O}$ values are observed in the $G$. ruber isotope profile at the core top and at the last interglacial substage 5e. This would imply that temperatures at the last climatic optimum (about 6-9 k.y.B.P.) and at the last interglacial have been warmer by $3^{\circ}-5^{\circ} \mathrm{C}$ than the modern SST. However, pollen records from cores collected in the northern Arabian Sea (Van Campo et al., 1982; Prell and Van Campo, 1986) indicate increased southwest monsoon winds during both these time periods which would have resulted in enhanced upwelling intensity and thus increased (i.e., "colder") planktonic $\delta^{18} \mathrm{O}$ values.

The reliability of SST estimates made strictly on the basis of planktonic $\delta^{18} \mathrm{O}$ inherently depends on the preferred species-specific temperature habitat, the assumed slope of $\delta^{18} \mathrm{O}$ equilibrium 
fractionation with respect to temperature, and on local variations of surface water $\delta^{18} \mathrm{O}_{\text {seawater }}$. For instance, large-scale injections of ${ }^{18} \mathrm{O}$-depleted meltwaters from waning Tibetan glaciers at the end of major glaciations could be one explanation for the pronounced negative excursions of planktonic $\delta^{18} \mathrm{O}$. However, this suggestion begs the question as to why there is no similar meltwater spike at the end of full-glacial stages 8 and 10 . Variations of the clay mineral assemblages in the Western Arabian Sea have been considered to indicate increased river runoff from the coast of Oman during periods of enhanced humidity in the early Holocene (Sirocko, 1989). That is, the surface water $\delta^{18} \mathrm{O}_{\text {seawater }}$ values at the Oman Margin could have varied as a function of continental humidity which is in turn monsoondriven. The SST recorded in $\delta^{18} \mathrm{O}$ of planktonic foraminifers depends further on the species-specific environmental preferences, the recorded SST lying between the mean preferred temperature and the true mean water temperature (Mix, 1987). For our $\delta^{18} \mathrm{O}$ SST estimates this means that a preference of $G$. ruber to calcify during the warmer nonupwelling winter season, for instance, would diminish the value of our records as an indicator for upwelling-driven SST variations. However, comparison with the organic carbon accumulation profile (open circles in Fig. 10C) shows at least some qualitative correlation between warmer SST and low carbon accumulation and vice versa during isotope stages 3, 5, 7, and 9 (Fig. 10C). This correlation breaks down during stages 6 and 9 where relative SST minima correlate with carbon accumulation minima (Fig. 10C). Furthermore, comparison with the orbital insolation monsoon index (MI; as defined by Rossignol-Strick, 1983) shows no correlation $\left(\mathrm{r}^{2}<0.1, \mathrm{n}=\right.$ 113) between predicted enhanced monsoon-driven upwelling and estimated SST and organic carbon anomalies (Fig. 10C).

The downcore profile of estimated SST oscillation implies that local temperatures were in general colder during glacial stages than during interglacial stages (Fig. 10C). This appears to be consistent with the conclusions of ten Haven and Kroon (this volume) who used the $U_{37}^{K}$ ratio in the lipid fraction of sediments from the Owen Ridge to infer that the SST in the northern Arabian Sea was $2^{\circ}-3^{\circ} \mathrm{C}$ colder during glacial periods than today. They suggested that the lower temperatures reflected cooling by cold adiabatic winds issuing from the Tibetan glaciers as a component of the prevailing northeasterlies. Such SST changes would have been superimposed on the upwelling-driven SST variations and could thus be another explanation for the poor correlation between the predicted strength of the monsoonal winds and our SST estimates.

\section{The Benthic Intermediate Water Isotope Record}

The intermediate water hydrography at the Oman margin is determined by the coastal upwelling regime and the advection of Red Sea outflow waters at depth. As mentioned earlier, the combination of high rates of input of organic matter from the highly productive surface waters and subsequent oxidation below the thermocline together with low renewal rates of intermediate depth waters result in a pronounced oxygen deficiency between 200 and $1500 \mathrm{~m}$. Marine organic matter and the $\mathrm{CO}_{2}$ which is released during its oxidation and added to the ambient water $\mathrm{\Sigma CO}_{2}$ are significantly depleted in $\delta^{13} \mathrm{C}(-20 \%$ to $-25 \%$ PDB). As a result, $\delta^{13} \mathrm{C}_{\Sigma \mathrm{CO}_{2}}$ values in the mid-depth Arabian Sea are depleted when compared to the regional deep waters (e.g., Kroopnick, 1985). Warm and saline outflow waters from the Red Sea alter the temperature and salinity characteristics of the local intermediate waters (Fig. 1). In addition, Red Sea waters have increased $\delta^{13} \mathrm{C}_{\mathrm{ECO}_{2}}$ values of about $+0.9 \%$ as revealed by the vertical isotope profile of Geosecs Station 407 at the northern entrance of the Bab el Mandab Strait (Östlund et al., 1987). Also, Red Sea $\delta^{18} \mathrm{O}_{\text {seawater }}$ values of $+1.9 \%$ (SMOW) (Craig, 1966) are considerably higher than the $\delta^{18} \mathrm{O}_{\text {seawater }}$ values of $+0.2 \%$ to
$+0.4 \%$ (SMOW) which are encountered below the core layer of Red Sea outflow water in the Arabian Sea (Fig. 11A). Therefore, variations of the organic carbon flux from the surface waters and of the advective flow from the Red Sea during the late Pleistocene have the potential to alter considerably the benthic $\delta^{18} \mathrm{O}$ and $\delta^{13} \mathrm{C}$ records at Site 724.
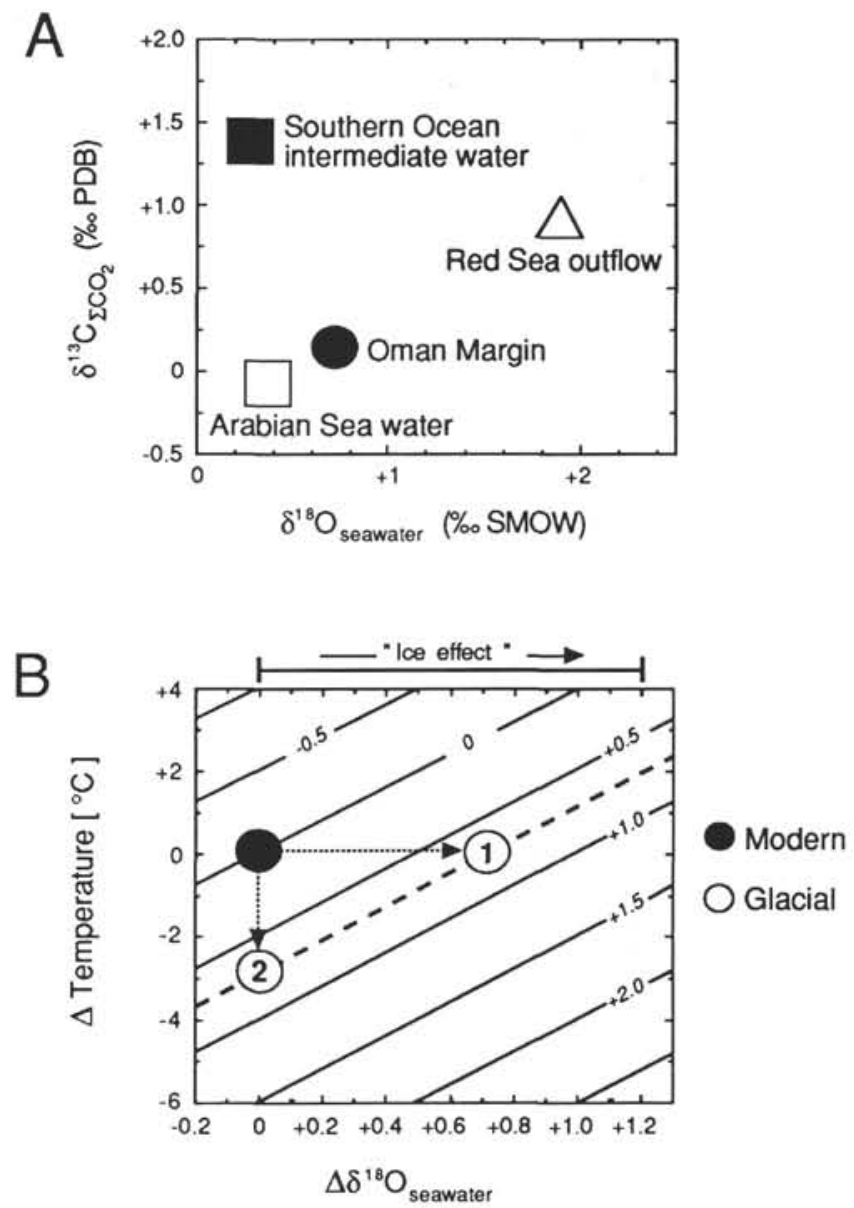

Figure 11. A. $\delta^{18} \mathrm{O}_{\text {seawater }}-\delta^{13} \mathrm{C}_{\Sigma \mathrm{CO}_{2}}$ composition of water masses in the Arabian Sea. Red Sea outflow data are from Geosecs station 407 $\left(\delta^{13} \mathrm{C}_{\Sigma \mathrm{CO}_{2}}\right)$ to the north of the Bab el Mandab Strait and from Craig (1966) $\left(\delta^{18} \mathrm{O}_{\text {seawater }}\right)$. Arabian Sea data are from Geosecs stations 413 , 416,417 , and 418 at depth of about $1000 \mathrm{~m}$, i.e., below the core layer of Red Sea waters. The isotope composition of intermediate waters at the Oman Margin was estimated by assuming a mixing ratio of $2: 8$ between Red Sea waters and Arabian Sea waters (Siedler, 1968). Southern Ocean intermediate water data are from Geosecs stations 427, 428, and 429 at depths between 400 and $600 \mathrm{~m}$. All Geosecs data are from Östlund et al. (1987). A cessation of Red Sea outflow and its replacement by Southern Ocean waters would result in a depletion of $\delta^{18} \mathrm{O}_{\text {seawater }}$ at Site 724 by about $0.4 \% 0$ whereas the $\delta^{13} \mathrm{C}_{\Sigma \mathrm{CO}_{2}}$ values would remain about the same or increase slightly. B. Temperature- $\delta^{18} \mathrm{O}_{\text {seawater }}$ plot showing isolines of equilibrium $\delta^{18} \mathrm{O}_{\text {calcite }}$ (calculated using the paleotemperature equation of Shackleton, 1974). Glacial 1: All of the glacial-interglacial benthic $\delta^{18} \mathrm{O}$ shift is due to changes in $\delta^{18} \mathrm{O}_{\text {seawater }}(1.2 \%$ ice volume minus $0.4 \%$ due to diminished Red Sea outflow). Glacial 2: All of the glacial-interglacial benthic $\delta^{18} \mathrm{O}$ shift is due to changes in seawater temperature. Assuming an enhanced influence of cold and ${ }^{18} \mathrm{O}$-depleted AAIW on the mid-depth hydrography at Site 724 , a true glacial point in the diagram may be somewhere between 1 and $2 ; \delta^{18} \mathrm{O}_{\text {seawater }}$ of this glacial AAIW must have been depleted by at least $0.5 \% 0-1.2 \%$ relative to the ambient waters so as to compensate the temperature effect. 
The mean ocean $\delta^{18} \mathrm{O}_{\text {seawater }}$ change between the last glacial maximum (approximately 18,000 yr ago) and the present interglacial has been estimated to be about 1.2-1.3\%0 (Labeyrie et al., 1987; Fairbanks, 1989). This global isotope shift is of about the same order as the apparent $\delta^{18} \mathrm{O}_{\text {seawater }}$ contrast between Red Sea waters and Arabian Sea waters. Global sea level was lower at the last glacial maximum by about $120 \mathrm{~m}$ (Chappell and Shackleton, 1986) and probably even lower during glacial-maximum oxygen isotope stages 6,10 , and 12 . During these stages benthic isotope records show $\delta^{18} \mathrm{O}$ values which are usually more positive than those observed at the last glacial maximum implying the existence of even larger global ice volumes and therefore lower sea level stands than at $18,000 \mathrm{yr}$ ago. As the sill depth between the Red Sea and the Gulf of Aden is only about $140 \mathrm{~m}$, the connection between the Red Sea and the Indian Ocean must have been reduced in depth to $<20 \mathrm{~m}$ or even entirely closed off during glacial periods. As a consequence, the advective flow from the Red Sea to the mid-depth Arabian Sea would have been reduced or entirely shut down during glacial maxima. As Figure 11A shows, the net effect of a complete cessation of the Red Sea outflow and replacement by Arabian Sea waters would be a decrease of $\delta^{18} \mathrm{O}_{\text {seawater }}$ and $\delta^{13} \mathrm{C}_{\Sigma \mathrm{CO}_{2}}$ at Site 724 by respectively $0.4 \% 0$ and $0.3 \%$. Comparing our benthic $\delta^{18} \mathrm{O}$ record with the synthetic $\delta^{18} \mathrm{O}_{\text {seawater }}$ record indeed indicates that the $\delta^{18} \mathrm{O}$ values at Site 724 during glacial stages $2-4$ and 6 are more negative by $0.3 \% 0-0.5 \%$ than expected strictly on the basis of the ice volume- $\delta^{18} \mathrm{O}_{\text {seawater }}$ effect (Fig. 12A). The depleted benthic $\delta^{18} \mathrm{O}$ values during glacial periods could therefore be explained by then reduced (or absent) advection of Red Sea waters to the Arabian Sea. Heavier than expected $\delta^{18} \mathrm{O}$ values are recorded during interglacial substage $5 \mathrm{e}$ and stage 7 , and during early gla-
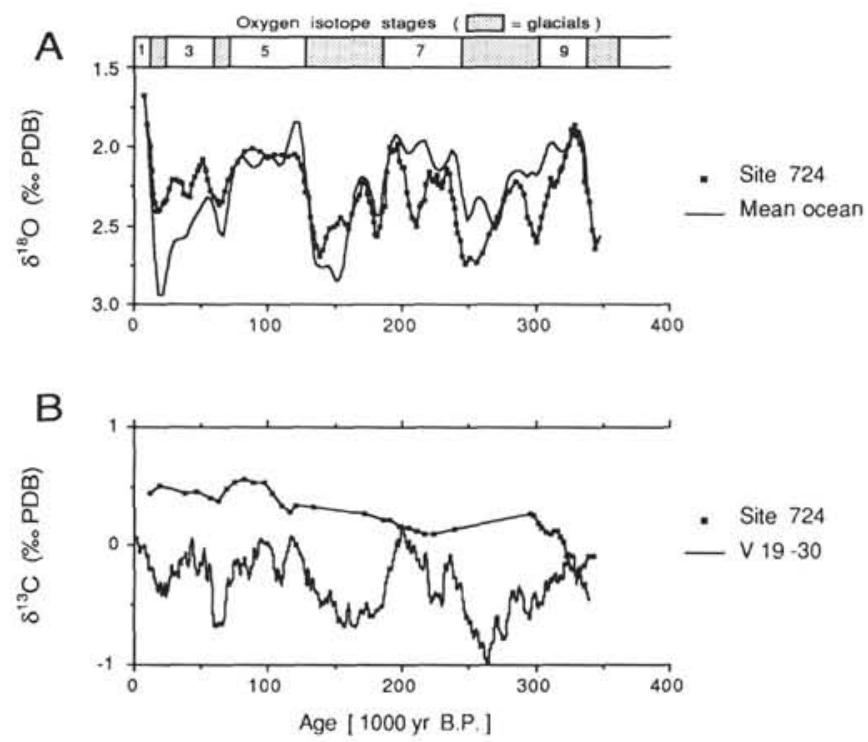

Figure 12. A. Comparison of the smoothed benthic $\delta^{18} \mathrm{O}$ record at Site 724 (solid squares) with the mean-ocean variation of $\delta^{18} \mathrm{O}_{\text {seawater }}$ (bold line). The $\delta^{18} \mathrm{O}_{\text {seawater }}$ record is the same as in Figure 9C with the exception that its interglacial isotope level was adjusted to the benthic core top value of $+1.9 \%$ (PDB). B. The smoothed epibenthic $\delta^{13} \mathrm{C}$ record from Site 724 (open squares) is compared to the deep-ocean $\delta^{13} \mathrm{C}$ record of core V19-30 (solid line) (Cibicidoides scale; Shackleton and Pisias, 1985). We interpret the combined signal of depleted benthic $\delta^{18} \mathrm{O}$ and constant or enriched epibenthic $\delta^{13} \mathrm{C}$ as documenting the replacement of Red Sea outflow waters by intermediate waters low in $\delta^{18} \mathrm{O}_{\text {seawater }}$ and similar or increased in $\delta^{13} \mathrm{C}_{\mathrm{E} \mathrm{CO}_{2}}$. These waters could have originated from the Southern Ocean (see text and Fig. 11). cial stage 8 . At this point we cannot determine whether these isotope features reflect real hydrographic signals or whether they are due to inaccurate $\delta^{18} \mathrm{O}_{\text {seawater }}$ estimates and/or downslope advection of sediments from shallower ("warmer") water depths.

The epibenthic $\delta^{13} \mathrm{C}$ record is far too incomplete to permit a detailed evaluation of intermediate water $\delta^{13} \mathrm{C}_{\Sigma \mathrm{CO}_{2}}$ variations (Fig. 12B). The few data available do not show a systematic glacialinterglacial pattern of variation. $\delta^{13} \mathrm{C}$ values are more positive than the modern value (which is about $+0.2 \%$; see Fig. 11A and also core top value of Cibicidoides spp. in Fig. 7) during mid-stage 5 and at the last glacial maximum. From the last interglacial back to oxygen isotope stage 7 , the $\delta^{13} \mathrm{C}$ values show only minor variations and remain close to their modern level. The combined pattern of $\delta^{18} \mathrm{O}$ and $\delta^{13} \mathrm{C}$ variation at Site 724 (Fig. 12) suggests that glacial intermediate-depth waters at the Oman Margin were lower in $\delta^{18} \mathrm{O}_{\text {seawater }}$ than Red Sea waters but similar or occasionally even enriched in $\delta^{13} \mathrm{C}_{\mathrm{ECO}_{2}}$.

Modern sources for intermediate water in the Northern Indian Ocean are manifold and include Pacific waters which are advected by way of the Banda Sea (Godfrey and Golding, 1981), south equatorial intermediate waters (Luyten et al., 1980; Quadfasel and Schott, 1982), and possible upwelling of waters from deep western boundary currents (Warren, 1981). The isotopic compositions of these water masses are largely unknown and therefore we cannot define the ultimate origin of the benthic $\delta^{18} \mathrm{O} / \delta^{13} \mathrm{C}$ variations at Site 724 . However, glacial-interglacial benthic isotope variations at intermediate water sites were considerably different from those at pelagic core sites throughout the northern Indian Ocean (Kallel et al., 1988). This may point to the existence of large-scale convection such as occurs in the Southern Ocean. There, large negative $\delta^{18} \mathrm{O}$ anomalies have been observed in glacial sections of planktonic $\delta^{18} \mathrm{O}$ records which have been interpreted as documenting enhanced meltwater input during successive surges of the ice shelves (Labeyrie et al., 1986). This meltwater contribution could enhance the low- $-\delta^{18} \mathrm{O}_{\text {seawater }}$ character of Antarctic Intermediate Water (AAIW) and thus partly explain the benthic $\delta^{18} \mathrm{O}$ depletion at Site 724 during glacial times.

Penetration of AAIW to the north is currently restricted to about $15^{\circ} \mathrm{S}$ by hydrographic fronts associated with the equatorial current system (e.g., Warren, 1981). In the absence of the Red Sea source for intermediate waters, AAIW could have spread farther north, thus influencing the ambient water hydrography at Site 724 (see, e.g., Kallel et al., 1988). The $\delta^{18} \mathrm{O}_{\text {seawater }}$ signal of this glacial AAIW must have been more negative by at least $0.4 \%_{0}-1.2 \%$ so as to compensate the effect that its low temperature would have had on the benthic $\delta^{18} \mathrm{O}$ values at Site 724 (Fig. 11B). Because a further depletion in dissolved oxygen at the Oman Margin appears inconceivable, the low epibenthic $\delta^{13} \mathrm{C}$ values prior to stage 8 (Fig. 12C) most likely imply a shift from low- $\delta^{13} \mathrm{C}_{\Sigma \mathrm{CO}}$ to high- $\delta^{13} \mathrm{C}_{\Sigma \mathrm{LO}_{2}}$ source waters, i.e., a shift in the preformed $\delta^{13} \mathrm{C}_{\mathrm{ECO}_{2}}$ value.

\section{Uvigerina spp. $\delta^{13} \mathrm{C}$ and Organic Carbon Variations: Records of Pore Water $\delta^{13} \mathrm{C}_{\Sigma \mathrm{CO}_{2}}$ and Paleoproductivity}

The $\delta^{13} \mathrm{C}$ record obtained from endobenthic Uvigerina spp. appears to vary independently from that of epibenthic Cibicidoides spp. (Fig. 7). The interspecific difference in $\delta^{13} C\left(\Delta \delta^{13} C\right)$ has already been proposed to be driven by varying burial rates of organic carbon and oxidation of organic matter in the sediments (Zahn et al., 1986; McCorkle et al., 1989). This relationship has been confirmed by the comparison of in-situ measurements of pore water $\delta^{13} \mathrm{C}_{\Sigma \mathrm{CO}_{2}}$ and organic carbon fluxes at the respective sites (McCorkle, 1987). The preservation of the $\delta^{13} \mathrm{C}_{\mathrm{ECO}}$ gradient of pore water to bottom water in turn appears to be primarily controlled by the thickness of the stagnant sublayer above the sediment surface (Archer et al., 1989). In this view, in- 
creased $\Delta \delta^{13} \mathrm{C}$ values would suggest that the burial rate of organic matter was generally enhanced during glacial times (Fig. 13A). However, intermediate water $\delta^{13} \mathrm{C}_{\Sigma \mathrm{CO}_{2}}$ at Site 724 appears to be highly variable through time as a function of various source water $\delta^{13} \mathrm{C}_{\mathrm{ECO}_{2}}$ and hence, one could argue that the $\Delta \delta^{13} \mathrm{C}$ variations through time at Site 724 are also a function of the preformed intermediate water $\delta^{13} \mathrm{C}_{\Sigma \mathrm{CO}_{2}}$. It is especially important to note that the variation seen in the interspecific $\Delta \delta^{13} \mathrm{C}$ values at Site 724 reflects primarily $\delta^{13} \mathrm{C}$ fluctuations of endobenthic $U v i$ gerina spp. (compare Fig. $13 \mathrm{~A}$ with the benthic $\delta^{13} \mathrm{C}$ profiles in Fig. 7), which appears to record the organic carbon flux more faithfully than the epibenthic Cibicidoides spp. In fact, the Uvigerina spp. $\delta^{13} \mathrm{C}$ profile appears to trace the organic carbon accumulation profile during the past $200 \mathrm{k} . \mathrm{y}$. in that high carbon accumulation rates coincide with more negative Uvigerina spp. $\delta^{13} \mathrm{C}$ values, and vice versa (Fig. 13). Prior to this period, both parameters are not well correlated; whereas carbon accumulation varies at about the same or an even larger order, Uvigerina spp. $\delta^{13} \mathrm{C}$ remains comparatively stable.

As with the organic carbon accumulation rates, we do not observe any clear correlation between the orbital monsoon index (MI) which may be used as an indicator for enhanced monsoonal winds and more intense upwelling, and the Uvigerina spp. $\delta^{13} \mathrm{C}$ profile $\left(\mathrm{r}^{2}<0.1, \mathrm{n}=146\right)$. Maximum strengths of monsoonal winds (as indicated by high MI values) which correlate with organic carbon accumulation maxima during early stage 1 , mid and late stage 7 , and late stage 9 , do not correspond with corresponding Uvigerina spp. $\delta^{13} \mathrm{C}$ minima. The lack of correlation between the organic carbon accumulation rate, Uvigerina spp. $\delta^{13} \mathrm{C}$ and assumed monsoonal wind strength as predicted from the insolation monsoon index, begs the question: why do productivity indicators such as the abundance of the planktonic foraminifer Globigerina bulloides (Prell and Van Campo, 1986) presumably trace the history of upwelling at the Oman Margin more accurately than more direct tracers such as organic carbon? This apparent conflict cannot be resolved at present. Based on the data available to date it seems that the Oman Margin upwelling system is more complex than previously assumed, unless we infer that most of the signals recorded at Site 724 are disturbed by downslope sediment transport. Independent proxy records for SST and productivity, e.g., from transfer functions and the nutrient-related tracer $\mathrm{Cd} / \mathrm{Ca}$ are needed to better constrain variations of paleoproductivity at Site 724, and to support (or reject) the hypothesis that upwelling variations at the Oman Margin during the Quaternary should be primarily controlled by variations in strength of the monsoonal winds. Such records are not yet available.

\section{SUMMARY AND CONCLUSIONS}

Time series of benthic and planktonic $\delta^{18} \mathrm{O}$ and $\delta^{13} \mathrm{C}$, and of $\mathrm{C}_{\text {org }}$ have been obtained for the past $350,000 \mathrm{yr}$ at Site 724 . The $\delta^{13} \mathrm{C}$ record of endobenthic Uvigerina spp. varies by up to $1 \% 0$ over the last three glacial-interglacial cycles. At the same time, $\delta^{13} \mathrm{C}$ values recorded by epibenthic Cibicidoides spp. remain constant or are slightly increased. The Uvigerina spp. $\delta^{13} \mathrm{C}$ profile traces variations in organic carbon accumulation during the past
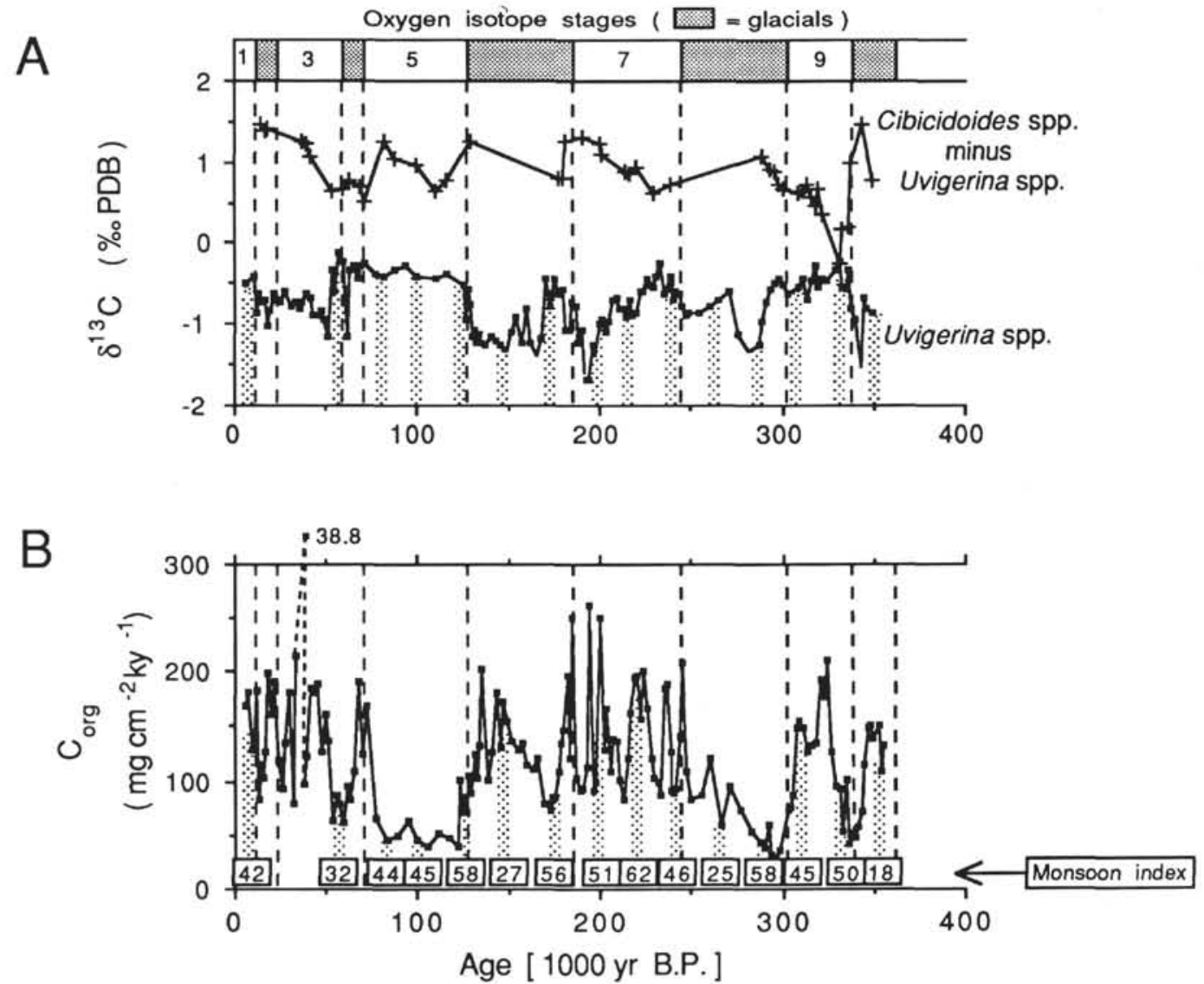

Figure 13. Comparison of the benthic $\delta^{13} \mathrm{C}$ productivity index (A) to the estimated variations of organic carbon accumulation (B). Uvigerina spp. $\delta^{13} \mathrm{C}$ traces the variations of organic carbon accumulation, at least during the past $200 \mathrm{ky}$. However, there is no clear correlation between the $\delta^{13} \mathrm{C}$ data, organic carbon accumulation and the orbital monsoon index. 
200,000 yr and supports the hypothesis that endobenthic $\delta^{13} \mathrm{C}$ should vary primarily as a function of the supply and oxidation of organic carbon in the upper few centimeters of the surface sediments (Zahn et al., 1986; McCorkle et al., 1989). Prior to this period, however, the correlation between Uvigerina spp. $\delta^{13} \mathrm{C}$ and accumulation of organic carbon is poor.

The planktonic $\delta^{18} \mathrm{O}$ record has been used to infer that glacial SSTs at the Oman Margin were lower than they are today. We have observed some graphical correlation between negative (colder) SST anomalies as deduced from planktic $\delta^{18} \mathrm{O}$ and enhanced carbon accumulation at Site 724. This implies an influence of upwelling intensity on paleoproductivity levels, as has been previously observed at other upwelling regions. However, the combined SST- $\mathrm{C}_{\text {org }}$ signals do not correlate with the orbital monsoon index (MI) and with pollen indices which have both been used as proxies for the strength of monsoonal winds, and potential upwelling intensity (Van Campo et al., 1982; Rossignol-Strick, 1983; Prell and Van Campo, 1986). In view of our new data it appears quite surprising that faunal upwelling indices which are based on the relative abundance of $G$. bulloides presumably show a better correlation to the orbital monsoon index, and hence to potential upwelling intensity (Prell, 1984; Prell and Van Campo, 1986), than the more direct productivity proxy $\mathrm{C}_{\text {org }}$. Without independent SST and productivity estimates, e.g., from transfer function estimates and benthic-planktonic $\mathrm{Cd} / \mathrm{Ca}$ data, we cannot resolve this conflict.

The benthic $\delta^{18} \mathrm{O}$ record varies at a lower amplitude than the estimated $\delta^{18} \mathrm{O}_{\text {seawater }}$ record. In respect to the constant or elevated epibenthic $\delta^{13} \mathrm{C}$ levels we conclude that the source of intermediate waters systematically changed between glacial and interglacial periods. During interglacials the mid-depth hydrography at the Oman Margin is significantly influenced by outflow waters from the Red Sea. Red Sea waters are increased in both $\delta^{18} \mathrm{O}_{\text {seawater }}$ and $\delta^{13} \mathrm{C}_{\Sigma \mathrm{CO}_{2}}$. During glacial periods the Bab el Mandab Strait was reduced to $<20 \mathrm{~m}$ in depth or even completely closed off so that advection of Red Sea waters to the Arabian Sea was drastically reduced if not completely switched off. The benthic isotope data imply that there was advection of intermediate waters to the Oman Margin which were still enriched in $\delta^{13} \mathrm{C}_{\mathrm{ECO}}$ but depleted in $\delta^{18} \mathrm{O}_{\text {seawater. }}$ These waters could have originated from the Southern Ocean where modern intermediate waters are enriched in $\delta^{13} \mathrm{C}_{\mathrm{ECO}}$ with respect to the underlying deep and bottom waters. Glacial depletion in $\delta^{18} \mathrm{O}_{\text {seawater }}$ of Southern Ocean intermediate waters could have been caused by sporadic surges of the ice shelf (Labeyrie et al., 1986).

In general, the constantly enriched epibenthic $\delta^{13} \mathrm{C}$ data at Site 724 appear to be consistent with similar observations from the mid-depth North Atlantic and North Pacific Oceans and support the hypothesis (Boyle, 1988b) that the hydrochemical cycles of the mid-depth ocean during glacial-interglacial times are decoupled from those of the abyssal ocean. Comparison of suitable geochemical proxy records from shallow and deep HPC cores which have been obtained during Leg 117 may eventually provide the first long time series for studying the long-term behavior of the ocean's vertical asymmetry and its relation to global climatic change.

\section{ACKNOWLEDGMENTS}

We are very grateful to the shipboard technical staff during Leg 117 for their assistance with sampling. In particular, the efforts of Bob Wilcox are highly appreciated. We would like to thank Bente Nielsen for her careful operation of the mass spectrometer at UBC, and Shirley French and Mark Noyon for their assistance in the preparation of the foraminifer samples. We are grateful to Shirley French and Maureen Soon for carefully running the carbon analyses. Laurent Labeyrie provided us with a digitized version of his mean-ocean $\delta^{18} \mathrm{O}_{\text {seawater }}$ record, and Bill Busch expeditiously supplied bulk density data on short notice. The manuscript benefitted from constructive reviews by Warren Prell, Alan Mix, Dick Kroon, William Curry, and an anonymous reviewer. TFP acknowledges the financial support of the Natural Sciences and Engineering Research Council of Canada.

\section{REFERENCES}

Archer, D., Emerson, S., and Smith, C., 1989. Direct measurement of the diffusive sublayer at the deep sea floor using oxygen microelectrodes. Nature, 340:623-626.

Balsam, W. L., and Posmenier, E. S., 1981. Comments on spectral analysis of core data. Palaeogeogr., Palaeoclimatol., Palaeoecol., 45: 369-372.

Berger, W. H., Diester-Haas, L., and Killingley, J. S., 1978. Upwelling off Northwest Africa: the Holocene decrease as seen in carbon isotopes and sedimentological indicators. Oceanol. Acta, 1:1-7.

Berger, W. H., and Heath, G. R., 1968. Vertical mixing in pelagic sediments. J. Mar. Res., 26:134-143.

Bethoux, J. P., 1987. Variabilité climatique des échanges entre la Mer Rouge et l'Océan Indian. Oceanol. Acta, 10:285-291.

1988. Red Sea geochemical budgets and exchanges with the Indian Ocean. Mar. Chem., 24:83-92.

Boyle, E. A., 1988a. Cadmium: chemical tracer of deepwater paleoceanography. Paleoceanography, 3:471-490.

$1988 \mathrm{~b}$. The role of vertical chemical fractionation in controlling late Quaternary atmospheric carbon dioxide. J. Geophys. Res., 93:15701-15714.

Chappell, J., and Shackleton, N. J., 1986. Oxygen isotopes and sea level. Nature, 324:137-140.

CLIMAP Project Members, 1984. The last interglacial ocean. Quat. Res., 21:123-224.

Corliss, B. H., 1985. Microhabitats of benthic foraminifera within deepsea sediments. Nature, 314:435-438.

Craig, H., 1966. Isotopic composition and origin of the Red Sea and Salton Sea geothermal brines. Science, 154:1544-1548.

Curry, W. B., Duplessy, J. C., Labeyrie, L. D., and Shackleton, N. J., 1988. Changes in the distribution of $\delta^{13} \mathrm{C}$ of deep water $\mathrm{\Sigma CO}_{2}$ between the last glacial and the Holocene. Paleoceanography, 3:317341.

Cushing, D. H., 1973. Production in the Indian Ocean and the transfer from the primary to the secondary level. In Zeitschel B. (Ed.), The Biology of the Indian Ocean. New York (Springer).

Düing, W., and Leetmaa, A., 1980. Arabian Sea cooling: a preliminary heat budget. Bull. Am. Meteorol. Soc., 10:307-312.

Düing, W., and Schwill, W.-D., 1968. Ausbreitung und Vermischung des salzreichen Wassers aus dem Roten Meer und aus dem Persischen Golf. "Meteor" Forschungsergeb. Reihe A, 3:44-66.

Duplessy, J. C., 1982. Glacial to interglacial contrasts in the northern Indian Ocean. Nature, 295:494-498.

Duplessy J. C., Shackleton, N. J., Fairbanks, R. G., Labeyrie, L., Oppo, D., and Kallel, N., 1988. Deepwater source variations during the last climatic cycle and their impact on global deepwater circulation. $\mathrm{Pa}$ leoceanography, 3:343-360.

Fairbanks, R. G., 1989. A 17,000-year glacio-eustatic sea level record: influence of glacial melting rates on the Younger Dryas event and deep-ocean circulation. Nature, 342:637-642.

Ganssen, G., and Sarnthein, M., 1983. Stable-isotope composition of foraminifers: the surface and bottom water record of coastal upwelling. In Suess, E., and Thiede, J. (Eds.), Coastal Upwelling, Its Sediment Record. New York (Plenum), 10A:99-121.

Godfrey, J. S., and Golding, T. J., 1981. The Sverdrup relation in the Indian Ocean, and the effect of Pacific-Indian Ocean throughflow on Indian Ocean circulation and on the East Australian Current. $J$. Phys. Oceanogr., 11:771-779.

Imbrie, J., Hays, J. D., Martinson, D. G., McIntyre, A., Mix, A. C., Morley, J. J., Pisias, N. G., Prell, W. L., and Shackleton, N. J., 1984. The orbital theory of Pleistocene climate: support from a revised chronology of the marine delta $\delta^{18} \mathrm{O}$ record. In Berger, A., Imbrie, J., Hays, J., Kukla, G., and Saltzman, B. (Eds.), Milankovitch and Climate (Pt. 1): Dordrecht (D. Reidel), 269-305.

Kabanova, Yu. G., 1968. Primary production of the northern part of the Indian Ocean. Oceanography, 8:214-225. 
Kaliel, N., Labeyrie, L. D., Juillet-Leclerc, A., and Duplessy, J.-C., 1988. A deep hydrological front between intermediate and deep-water masses in the glacial Indian Ocean. Nature, 333:651-655.

Krey, J., 1973. Primary production in the Indian Ocean. In Zeitzschel, B., and Gerlach, S. A. (Eds.), The Biology of the Indian Ocean: New York (Springer-Verlag), 115-126.

Kroon, D., and Ganssen, G., 1989. Northern Indian Ocean upwelling cells and the stable isotope composition of living planktonic foraminifers. Deep-Sea Res. Part A, 36:1219-1236.

Kroopnick, P., 1980. The distribution of ${ }^{13} \mathrm{C}$ in the Atlantic Ocean. Earth Planet. Sci. Lett., 49:469-484.

Labeyrie, L., Pichon, J.-J., Labracherie, M., Ippolito, P., Duprat, J., and Duplessy, J.-C., 1986. Melting history of Antarctica during the past 60,000 years. Nature, 322:701-706.

Labeyrie, L. D., Duplessy, J. C., and Blanc, P. L., 1987. Variations in mode of formation and temperature of oceanic deep waters over the past 125,000 years. Nature, 327:477-482.

Lutze, G. F., 1986. Uvigerina species of the eastern North Atlantic. In van der Zwaan, G. J., et al. (Eds.), Atlantic-European Oligocene to Recent Uvigerina. Utrecht Micropaleontol. Bull., 35:21-46.

Lutze, G. F., and Thiel, H., 1987. Cibicidoides wuellerstorfi and Planulina ariminensis, elevated epibenthic foraminifera. In Altenbach, A. V., et al. (Eds.), Beobachtungen an Benthos-Foraminiferen. Report Sonderforschungsbereich 313, Univ. of Kiel, Federal Republic of Germany: 17-30.

Luyten, J. R., Fieux, M., and Gonelia, J., 1980. Equatorial currents in the western Indian Ocean. Science, 209:600-602.

McCorkle, D. C., 1987. Stable carbon isotopes in deep sea pore waters: modern geochemistry and paleoceanographic applications. [Ph.D. dissert.]. Univ. Washington.

McCorkle, D. C., Emerson, S. R., and Quay, P., 1985. Stable isotopes in marine pore waters. Earth Planet. Sci. Lett., 74:13-26.

McCorkle, D. C., Keigwin, L. D., Corliss, B. R., and Emerson, S. R., 1989. The $\delta^{13} \mathrm{C}$ of Uvigerina and the pore water $\delta^{13} \mathrm{C}$ gradient at the sediment-water interface. Third Inter. Conf. on Paleoceanography, London (Blackwell Scientific Publications), 63.

Mix, A. C., 1987. The oxygen isotope record of glaciation. In Ruddiman, W. F., and Wright, H. E. (Eds.), North America and Adjacent Oceans during the Last Deglaciation, The Geology of North America (Vol. K-3): Geol Soc. Am., 111-135.

Nair, R. R., Ittekkot, V., Manganini, S. J., Ramaswamy, V., Haake, B., Degens, E. T., Desai, B. N., and Honjo, S., 1989. Increased particle flux to the deep ocean related to monsoons. Nature, 338:749-751.

Ostlund, H. G., Craig, C., Broecker, W. S., and Spencer, D. (Eds.), 1987. Geosecs Atlantic, Pacific, and Indian Ocean expeditions. Shorebased data and graphics. Geosecs Atlas Series (Vol. 7): Washington (U.S. Govt. Printing Office).

Prell, W. L., 1984. Monsoonal climate of the Arabian Sea during the late Quaternary: a response to changing solar radiation. In Berger, A. L., Imbrie, J., Hays, J., Kukla, G., and Saltzman, B. (Eds.). Milankovitch and Climate (Pt. 1): Dordrecht (D. Reidel), 349-366.

Prell, W. L., and Curry, W. B., 1981. Faunal and isotopic indices of monsoonal upwelling: western Arabian Sea. Oceanol. Acta, 4:9198.

Prell, W. L., and Van Campo, E., 1986. Coherent response of Arabian Sea upwelling and pollen transport to late Quaternary monsoonal winds. Nature, 323:526-528.

Premchand, K., Sastry, J. S., and Murty, C. S., 1986a. Watermass structure in the western Indian Ocean-Part III: the spreading and transformation of Red Sea watermass. Mausam, 37:317-324.

1986b. Watermass structure in the western Indian OceanPart II: the spreading and transformation of Persian Gulf water. Mausam, 37:179-186.
Qasim, S. Z., 1982. Oceanography of the northern Arabian Sea. DeepSea Res. Part A, 29:1041-1068.

Quadfasel, D. R., and Schott, F., 1982. Water mass distributions at intermediate layers off the Somali Coast during the onset of the southwest monsoon 1979. J. Phys. Oceanogr., 12:1358-1372.

Resig, J., 1981. Biogeography of benthic foraminifera of the northern Nazca Plate and adjacent continental margin. In Kulm, L., Dymond, J., Dasch, E. J., and Hussong, D. (Eds.), Nazca Plate: Crustal Formation and Andean Convergence. Mem. Geol. Soc. Am., 154: 619-666.

Rossignol-Strick, M., 1983. African monsoons, an immediate climate response to orbital insolation. Nature, 304:46-49.

Schemainda, R., Nehring, D., and Schulz, S., 1975. Ozeanologische Untersuchungen zum Produktionspotential der nordwestafrikanischen Wasserauftriebsregion 1970-1973. Geod. Geophys. Veröff., 16:3-84.

Schott, F., and Quadfasel, D. R., 1982. Variability of the Somali Current system during the onset of the southwest monsoon of 1979. J. Phys. Oceanogr., 12:1343-1357.

Shackleton, N. J., and Opdyke, N. D., 1973. Oxygen isotope and palaeomagnetic stratigraphy of Equatorial Pacific core V28-238: oxygen isotope temperatures and ice volumes on a $10^{5}$ year and $10^{6}$ year scale. Quat. Res., 3:39-55.

Shackleton, N. J., and Pisias, N. G., 1985. Atmospheric carbon dioxide, orbital forcing, and climate. In Sundquist, E. T., and Broecker, W. S. (Eds.), The Carbon Cycle and Atmospheric $\mathrm{CO}_{2}:$. Natural Variations Archean to Present. Am. Geophys. Union Monogr., 32: 303-317.

Siedler, G., 1968. Schichtungs und Bewegungsverhältnisse am Südausgang des Roten Meeres. "Meteor" Forschungsergeb. Reihe A, 4: $1-76$.

Sirocko, F., 1989. Accumulation of eolian sediments in the northwest Indian Ocean: record of the climatic history of Arabia and India. Rep. Geol. Inst. Kiel, 27.

Souvermezoglou, E., Metzl, N., and Poisson, A., 1989. Red Sea budgets of salinity, nutrients and carbon calculated in the Strait of BabEl-Mandab during the summer and winter seasons. J. Mar. Res., 47: 441-456.

Swallow, J. C., Molinari, R. L., Bruce, J. G., Brown, O. B., and Evans, R. H., 1983. Development of near-surface low pattern and water mass distribution in the Somali Basin in response to the southwest monsoon of 1979. J. Phys. Oceanogr., 13:1398-1415.

Van Campo, E., Duplessy, J. C., and Rossignol-Strick, M., 1982. Climatic conditions deduced from a 150-k.y. oxygen isotope-pollen record from the Arabian Sea. Nature, 296:56-59.

Warren, B. A., 1981. Transindian hydrographic section at Lat.18 ${ }^{\circ} \mathrm{S}$ : property distributions and circulation in the southern Indian Ocean. Deep-Sea Res. Part A, 28A:759-788.

Wyrtki, K., 1971. Oceanographic Atlas of the International Ocean Expedition: Washington (Nat. Sci. Found.).

1973. Physical oceanography of the Indian Ocean. In Zeitschel, B., and Gerlach, S. A. (Eds.), The Biology of the Indian Ocean (Vol. 3): New York (Springer-Verlag), 18-36.

Zahn, R., Sarnthein, M., and Erlenkeuser, H., 1987. Benthic isotope evidence for changes of the Mediterranean outflow during the late Quaternary. Paleoceanography, 2:543-559.

Zahn, R., Winn, K., and Sarnthein, M., 1986. Benthic foraminiferal $\delta^{13} \mathrm{C}$ and accumulation rates of organic carbon: Uvigerina peregrina group and Cibicidoides wuellerstorfi. Paleoceanography, 1:27-42.

Date of initial receipt: 2 October 1989

Date of acceptance: 8 May 1990

Ms 117B-162 
APPENDIX A

Stable isotope date for Site $\mathbf{7 2 4}$, hole C

\begin{tabular}{|c|c|c|c|c|c|c|c|c|c|}
\hline \multirow[b]{2}{*}{$\begin{array}{l}\text { Core, } \\
\text { section }\end{array}$} & \multirow{2}{*}{$\begin{array}{l}\text { Depth } \\
\text { in section } \\
(\mathrm{cm})\end{array}$} & \multirow{2}{*}{$\begin{array}{l}\text { Sub-bottom } \\
\text { depth } \\
\text { (m) }\end{array}$} & \multirow[b]{2}{*}{$\begin{array}{c}\text { Age } \\
\text { (1000 yrB.P.) }\end{array}$} & \multicolumn{2}{|c|}{ Uvigerina spp. } & \multicolumn{2}{|c|}{ Cibicidoides spp. } & G. rube & (white) \\
\hline & & & & $\begin{array}{c}\delta^{18} \mathrm{O} \\
(\% 0 \text { PDB })\end{array}$ & $\begin{array}{c}\delta^{13} \mathrm{C} \\
(\% \circ \mathrm{PDB})\end{array}$ & $\begin{array}{c}\delta^{18} \mathrm{O} \\
(\%, \mathrm{PDB})\end{array}$ & $\begin{array}{c}\delta^{13} \mathrm{C} \\
\left(\%_{0} \mathrm{PDB}\right)\end{array}$ & $\begin{array}{c}\delta^{18} \mathrm{O} \\
(\% \circ \mathrm{PDB})\end{array}$ & $\begin{array}{c}\delta^{13} \mathrm{C} \\
\left(\%_{00} \mathrm{PDB}\right)\end{array}$ \\
\hline $1 \mathrm{H}-1$ & $22-24$ & 0.22 & 6.133 & 1.180 & -0.490 & & & -3.010 & 1.230 \\
\hline $1 \mathrm{H}-1$ & $42-44$ & 0.42 & 7.467 & ${ }^{a} 2.160$ & $\mathrm{a}-0.600$ & 1.040 & 0.230 & -2.130 & 0.950 \\
\hline $1 \mathrm{H}-1$ & $62-64$ & 0.62 & 8.800 & $a_{2.630}$ & ${ }^{a}-0.650$ & $\mathrm{~b}_{1.370 / 0.926}$ & ${ }^{b} 0.210 / 0.133$ & -2.110 & 0.840 \\
\hline IH-1 & $82-84$ & 0.82 & 10.133 & 1.760 & -0.410 & $a_{1.435}$ & ${ }^{\mathrm{a}} 0.260$ & -1.910 & 0.790 \\
\hline $1 \mathrm{H}-1$ & $102-104$ & 1.02 & 11.467 & 1.990 & -0.850 & ${ }^{a} 1.589$ & ${ }^{\mathrm{a}} 0.349$ & -0.993 & 0.504 \\
\hline $1 \mathrm{H}-1$ & $122-124$ & 1.22 & 12.800 & 2.070 & -0.630 & & & -0.750 & 0.430 \\
\hline $1 \mathrm{H}-1$ & $142-144$ & 1.41 & 14.067 & 2.450 & -0.730 & 1.677 & 0.745 & -0.300 & 0.620 \\
\hline $1 \mathrm{H}-2$ & $12-14$ & 1.62 & 15.467 & 2.510 & -0.720 & ${ }^{a_{1.618}}$ & ${ }^{2} 0.632$ & -0.540 & 0.670 \\
\hline $1 \mathrm{H}-2$ & $32-34$ & 1.82 & 16.800 & 2.540 & -0.710 & 1.831 & 0.674 & -1.210 & 0.030 \\
\hline $1 \mathrm{H}-2$ & $52-54$ & 2.02 & 18.133 & 2.230 & -1.02 & 1.697 & 0.389 & -0.510 & 0.257 \\
\hline $1 \mathrm{H}-2$ & $72-74$ & 2.22 & 19.467 & 2.340 & -0.830 & & & -0.939 & 0.744 \\
\hline $1 \mathrm{H}-2$ & $92-94$ & 2.42 & 20.800 & 2.370 & -0.710 & & & -0.673 & 0.433 \\
\hline $1 \mathrm{H}-2$ & $108-110$ & 2.58 & 21.867 & 2.490 & -0.610 & ${ }^{a} 2.484$ & ${ }^{\mathrm{a}} 0.803$ & -0.573 & 0.433 \\
\hline $2 \mathrm{H}-1$ & 7-9 & 2.87 & 23.800 & 2.290 & -0.700 & $a_{1.289}$ & ${ }^{\mathrm{a}} 0.264$ & -0.887 & 0.523 \\
\hline $2 \mathrm{H}-1$ & $22-24$ & 3.02 & 25.193 & 2.252 & -0.718 & $a_{1.997}$ & ${ }^{a} 0.486$ & -0.646 & 0.377 \\
\hline $2 \mathrm{H}-1$ & $42-44$ & 3.22 & 27.182 & 2.280 & -0.600 & & & -0.463 & 0.640 \\
\hline $2 \mathrm{H}-1$ & $62-64$ & 3.42 & 29.170 & & & & & -0.612 & 0.490 \\
\hline $2 \mathrm{H}-1$ & $82-84$ & 3.62 & 31.159 & 2.010 & -0.790 & & & -0.478 & 0.651 \\
\hline $2 \mathrm{H}-1$ & $102-104$ & 3.82 & 33.148 & 2.200 & -0.740 & & & -0.520 & 0.460 \\
\hline $2 \mathrm{H}-1$ & $122-124$ & 4.02 & 35.136 & 2.310 & -0.820 & & & & \\
\hline $2 \mathrm{H}-1$ & $142-144$ & 4.22 & 37.125 & 2.260 & -0.720 & 1.646 & 0.541 & -0.561 & 0.499 \\
\hline $2 \mathrm{H}-2$ & $12-14$ & 4.42 & 39.114 & 2.310 & -0.630 & 1.702 & 0.605 & -1.024 & 0.640 \\
\hline $2 \mathrm{H}-2$ & $32-34$ & 4.62 & 41.102 & 2.440 & -0.670 & ${ }^{a} 1.655$ & ${ }^{\mathrm{a}} 0.403$ & -0.676 & 0.452 \\
\hline $2 \mathrm{H}-2$ & $52-54$ & 4.82 & 43.091 & 2.240 & -0.900 & & & -1.019 & 0.501 \\
\hline $2 \mathrm{H}-2$ & $72-74$ & 5.02 & 45.080 & 2.360 & -0.900 & & & -0.912 & 0.456 \\
\hline $2 \mathrm{H}-2$ & $92-94$ & 5.22 & 47.068 & 1.880 & -0.840 & ${ }^{a} 1.595$ & ${ }^{\mathrm{a}} 0.259$ & -0.978 & 0.299 \\
\hline $2 \mathrm{H}-2$ & $112-114$ & 5.42 & 49.057 & 2.090 & -0.940 & & & -1.837 & -0.079 \\
\hline $2 \mathrm{H}-2$ & $132-134$ & 5.62 & 51.045 & 2.170 & -1.140 & & & -0.580 & 0.276 \\
\hline $2 \mathrm{H}-3$ & 2-4 & 5.82 & 53.034 & 2.010 & -0.330 & 1.496 & 0.310 & -0.890 & 0.464 \\
\hline $2 \mathrm{H}-3$ & $22-24$ & 6.02 & 55.023 & 2.190 & -0.590 & $\mathrm{a}_{1.006}$ & ${ }^{\mathrm{a}} 0.285$ & -0.562 & 0.352 \\
\hline $2 \mathrm{H}-3$ & $42-44$ & 6.22 & 57.011 & 2.190 & -0.130 & ${ }^{a} 1.104$ & ${ }^{\mathrm{a}} 0.311$ & -1.599 & 0.517 \\
\hline $2 \mathrm{H}-3$ & $62-64$ & 6.42 & 59.000 & 2.350 & -0.220 & $b_{1.820 / 1.898}$ & $b_{0.430 / 0.472}$ & -1.199 & 0.682 \\
\hline $2 \mathrm{H}-3$ & $82-84$ & 6.62 & 61.000 & 2.510 & -1.14 & ${ }^{a} 1.602$ & ${ }^{\mathrm{a}} 0.483$ & -0.217 & 0.034 \\
\hline $2 \mathrm{H}-3$ & $102-104$ & 6.82 & 63.000 & 2.250 & -0.340 & 1.637 & 0.432 & -0.682 & 0.514 \\
\hline $2 \mathrm{H}-3$ & $122-124$ & 7.02 & 65.000 & 2.260 & -0.280 & & & -0.824 & 0.487 \\
\hline $2 \mathrm{H}-3$ & $142-144$ & 7.22 & 67.000 & 2.360 & -0.430 & & & -0.732 & 0.528 \\
\hline $2 \mathrm{H}-4$ & $12-14$ & 7.42 & 69.000 & 2.330 & -0.280 & 1.700 & 0.429 & -0.684 & 0.508 \\
\hline $2 \mathrm{H}-4$ & $32-34$ & 7.62 & 71.000 & 2.040 & -0.250 & 1.592 & 0.264 & -1.421 & 0.657 \\
\hline $2 \mathrm{H}-4$ & $52-54$ & 7.82 & 76.751 & 1.950 & -0.380 & ${ }^{\mathrm{a}} 0.951$ & ${ }^{\mathrm{a}} 0.158$ & -1.471 & 0.471 \\
\hline $2 \mathrm{H}-4$ & $72-74$ & 8.02 & 82.143 & 1.950 & -0.410 & 1.248 & 0.841 & -1.267 & 0.575 \\
\hline $2 \mathrm{H}-4$ & $92-94$ & 8.22 & 87.714 & 2.210 & -0.330 & 1.465 & 0.724 & -1.488 & 0.654 \\
\hline $2 \mathrm{H}-4$ & $112-114$ & 8.42 & 93.286 & 1.950 & -0.280 & $a_{1.633}$ & ${ }^{\mathrm{a}} 0.556$ & -1.359 & 0.694 \\
\hline $2 \mathrm{H}-4$ & $132-134$ & 8.62 & 98.857 & 1.990 & -0.400 & 1.466 & 0.577 & -1.498 & 0.753 \\
\hline $2 \mathrm{H}-5$ & $2-4$ & 8.82 & 104.429 & 2.040 & 0.000 & 1.421 & 0.301 & -1.347 & 0.013 \\
\hline $2 \mathrm{H}-5$ & $22-24$ & 9.02 & 110.000 & 2.060 & -0.440 & 1.526 & 0.209 & -1.592 & 0.782 \\
\hline $2 \mathrm{H}-5$ & $42-44$ & 9.22 & 116.000 & 2.090 & -0.380 & 1.371 & 0.392 & -2.046 & 0.427 \\
\hline $2 \mathrm{H}-5$ & $62-64$ & 9.42 & 122.000 & 1.990 & -0.442 & & & -2.670 & 0.620 \\
\hline $2 \mathrm{H}-5$ & $82-84$ & 9.62 & 123.182 & 2.090 & -0.380 & 1.459 & 0.189 & -1.562 & 0.426 \\
\hline $2 \mathrm{H}-5$ & $102-104$ & 9.82 & 124.364 & 1.930 & -0.478 & 1.436 & 0.360 & -1.487 & 0.011 \\
\hline $2 \mathrm{H}-5$ & $122-124$ & 10.02 & 125.545 & 2.170 & -0.520 & ${ }^{a} 0.700 / 0.930$ & $\mathrm{a}-0.030 / 0.030$ & & \\
\hline $2 \mathrm{H}-5$ & $142-144$ & 10.22 & 126.727 & 2.310 & -0.940 & & & -0.839 & 0.039 \\
\hline $2 \mathrm{H}-6$ & $12-14$ & 10.42 & 127.909 & 2.120 & -0.570 & ${ }^{a_{1}} .216$ & ${ }^{\mathrm{a} 0} 0.211$ & -0.931 & 0.053 \\
\hline $2 \mathrm{H}-6$ & $32-34$ & 10.62 & 129.091 & 2.410 & -0.750 & 1.933 & 0.509 & -0.772 & 0.141 \\
\hline $2 \mathrm{H}-6$ & $52-54$ & 10.82 & 130.273 & 2.350 & -1.140 & ${ }^{\mathrm{a}} 0.789$ & ${ }^{a} 0.051$ & -0.572 & -0.167 \\
\hline $2 \mathrm{H}-6$ & $72-74$ & 11.02 & 131.455 & 2.160 & -1.080 & & & -0.394 & 0.075 \\
\hline $2 \mathrm{H}-6$ & $92-94$ & 11.22 & 132.636 & 2.440 & -1.230 & & & -0.653 & -0.377 \\
\hline $2 \mathrm{H}-6$ & $112-114$ & 11.42 & 133.818 & 2.770 & -1.130 & & & -0.245 & -0.219 \\
\hline $2 \mathrm{H}-6$ & $132-134$ & 11.62 & 135.000 & 2.820 & -1.220 & $\mathrm{a}_{1.562}$ & ${ }^{a} 0.498$ & & \\
\hline $2 \mathrm{H}-7$ & $2-4$ & 11.82 & 137.769 & 2.560 & -1.270 & ${ }^{a} 1.697$ & ${ }^{\mathrm{a}} 0.106$ & -0.654 & 0.019 \\
\hline $2 \mathrm{H}-7$ & $22-24$ & 12.02 & 140.538 & 2.600 & -1.160 & ${ }^{a} 1.652$ & ${ }^{\mathrm{a}} 0.239$ & -0.571 & -0.161 \\
\hline $2 \mathrm{H}-7$ & $42-44$ & 12.22 & 143.308 & 2.710 & -1.210 & & & -0.301 & -0.225 \\
\hline $2 \mathrm{H}-7$ & $62-64$ & 12.42 & 146.077 & $b_{2.820 / 2.370}$ & ${ }^{b}-1.220 /-1.300$ & & & -0.521 & -0.189 \\
\hline $3 \mathrm{H}-1$ & $42-44$ & 12.62 & 148.846 & 2.380 & -1.340 & & & -0.484 & 0.201 \\
\hline $3 \mathrm{H}-1$ & $62-64$ & 12.82 & 151.615 & 2.260 & -1.110 & & & -0.566 & 0.188 \\
\hline $3 \mathrm{H}-1$ & $82-84$ & 13.02 & 154.385 & 2.570 & -0.910 & & & -0.380 & -0.016 \\
\hline $3 \mathrm{H}-1$ & $102-104$ & 13.22 & 157.154 & 2.590 & -1.230 & & & -0.728 & -0.078 \\
\hline $3 \mathrm{H}-1$ & $122-124$ & 13.42 & 159.923 & 2.430 & -0.800 & $a_{2.102}$ & ${ }^{\mathrm{a}} 0.030$ & -0.520 & 0.084 \\
\hline $3 \mathrm{H}-1$ & $142-144$ & 13.62 & 162.692 & 2.560 & -1.24 & $\mathrm{a}_{2.216}$ & ${ }^{\mathrm{a}} 0.332$ & -0.526 & 0.117 \\
\hline $3 \mathrm{H}-2$ & $12-14$ & 13.82 & 165.462 & 2.410 & -1.40 & ${ }^{a} 1.970 / 2.013$ & ${ }^{\mathrm{a}} 0.220 / 0.150$ & -0.410 & 0.185 \\
\hline $3 \mathrm{H}-2$ & $32-34$ & 14.02 & 168.231 & 2.150 & -1.17 & $\mathrm{a}_{1.749}$ & $a-0.063$ & -0.552 & -0.021 \\
\hline $3 \mathrm{H}-2$ & $52-54$ & 14.22 & 171.000 & 2.120 & -0.440 & & & -0.555 & 0.068 \\
\hline $3 \mathrm{H}-2$ & $72-74$ & 14.42 & 172.500 & 2.270 & -0.790 & ${ }^{a} 1.881$ & ${ }^{a} 0.036$ & -0.788 & -0.037 \\
\hline $3 \mathrm{H}-2$ & $92-94$ & 14.62 & 174.000 & 2.200 & -0.620 & $\mathrm{a}_{1.872}$ & ${ }^{\mathrm{a}} 0.241$ & -0.651 & 0.079 \\
\hline $3 \mathrm{H}-2$ & $112-114$ & 14.82 & 175.500 & 2.330 & -0.450 & $\mathrm{a}_{1.958}$ & ${ }^{\mathrm{a}} 0.213$ & -0.912 & -0.001 \\
\hline $3 \mathrm{H}-2$ & $132-134$ & 15.02 & 177.000 & 2.440 & -0.640 & 1.979 & 0.191 & -0.621 & -0.108 \\
\hline
\end{tabular}


Appendix A (continued).

\begin{tabular}{|c|c|c|c|c|c|c|c|c|c|}
\hline \multirow[b]{2}{*}{$\begin{array}{l}\text { Core, } \\
\text { section }\end{array}$} & \multirow{2}{*}{$\begin{array}{l}\text { Depth } \\
\text { in section } \\
(\mathrm{cm})\end{array}$} & \multirow{2}{*}{$\begin{array}{l}\text { Sub-bottom } \\
\text { depth } \\
\text { (m) }\end{array}$} & \multirow[b]{2}{*}{$\begin{array}{c}\text { Age } \\
\text { (1000 yrB.P.) }\end{array}$} & \multicolumn{2}{|c|}{ Uvigerina spp. } & \multicolumn{2}{|c|}{ Cibicidoides spp. } & G. rube & (white) \\
\hline & & & & $\begin{array}{c}\delta^{18} \mathrm{O} \\
\left(\%_{0} \mathrm{PDB}\right)\end{array}$ & $\begin{array}{c}\delta^{13} \mathrm{C} \\
(\% 0 \text { PDB })\end{array}$ & $\begin{array}{c}\delta^{18} \mathrm{O} \\
(\% 0 \text { PDB })\end{array}$ & $\begin{array}{c}\delta^{13} \mathrm{C} \\
(\% 0 \text { PDB })\end{array}$ & $\begin{array}{c}\delta^{18} \mathrm{O} \\
\left(\%_{0} \mathrm{PDB}\right)\end{array}$ & $\begin{array}{c}\delta^{13} \mathrm{C} \\
\left(\% \%_{0} \mathrm{PDB}\right)\end{array}$ \\
\hline $3 \mathrm{H}-3$ & $2-4$ & 15.22 & 178.500 & 2.390 & -0.590 & & & & \\
\hline $3 \mathrm{H}-3$ & $22-24$ & 15.42 & 180.000 & 2.600 & -0.580 & 1.947 & 0.215 & -0.487 & 0.029 \\
\hline $3 \mathrm{H}-3$ & $42-44$ & 15.62 & 181.500 & 2.500 & -1.070 & 1.948 & 0.188 & -0.313 & 0.062 \\
\hline $3 \mathrm{H}-3$ & $62-64$ & 15.82 & 183.000 & 2.700 & -1.060 & ${ }^{a} 1.813$ & ${ }^{\mathrm{a}} 0.189$ & -0.586 & -0.146 \\
\hline $3 \mathrm{H}-3$ & $82-84$ & 16.02 & 184.859 & 2.610 & -0.720 & & & & \\
\hline $3 \mathrm{H}-3$ & $102-104$ & 16.22 & 186.718 & 2.070 & -0.780 & ${ }^{a} 1.826$ & ${ }^{\mathrm{a}} 0.204$ & -0.615 & 0.101 \\
\hline $3 \mathrm{H}-3$ & $122-124$ & 16.42 & 188.577 & $b_{2.280 / 1.915}$ & b $-1.230 /-1.232$ & ${ }^{a} 1.694$ & ${ }^{\mathrm{a}} 0.187$ & -1.092 & -0.703 \\
\hline $3 \mathrm{H}-3$ & $142-144$ & 16.62 & 190.437 & 2.460 & -1.070 & 1.658 & 0.242 & -0.704 & -0.190 \\
\hline $3 \mathrm{H}-4$ & $12-14$ & 16.82 & 192.296 & 1.603 & -1.609 & ${ }^{a} 1.935$ & ${ }^{\mathrm{a}} 0.185$ & -0.688 & -0.174 \\
\hline $3 \mathrm{H}-4$ & $32-34$ & 17.02 & 194.155 & $b_{2.310 / 1.404}$ & $b-1.440 /-1.888$ & & & -0.682 & -0.368 \\
\hline $3 \mathrm{H}-4$ & $52-54$ & 17.22 & 196.014 & $b_{2.290 / 2.147}$ & b $-1.030 /-1.461$ & & & & \\
\hline $3 \mathrm{H}-4$ & $72-74$ & 17.42 & 197.873 & $b_{2.140 / 1.951}$ & $b-1.310 /-1.463$ & ${ }^{\mathrm{a}} 1.895$ & ${ }^{\mathrm{a}} 0.095$ & -0.997 & -0.312 \\
\hline $3 \mathrm{H}-4$ & $92-94$ & 17.62 & 199.732 & $b_{1} 1.720 / 2.452$ & $b-0.950 /-1.013$ & 1.630 & 0.253 & -0.722 & 0.079 \\
\hline $3 \mathrm{H}-4$ & $112-114$ & 17.82 & 201.592 & $b_{1.960 / 2.165}$ & $b-1.070 /-0.793$ & 1.518 & 0.166 & -0.733 & 0.036 \\
\hline $3 \mathrm{H}-4$ & $132-134$ & 18.02 & 203.451 & $b_{2.130 / 2.009}$ & $\mathrm{~b}-1.110 /-1.112$ & ${ }^{a} 1.915$ & ${ }^{a} 0.141$ & -0.742 & -0.828 \\
\hline $3 \mathrm{H}-5$ & $2-4$ & 18.22 & 205.310 & $\mathrm{~b}_{2.210 / 2.11}$ & b $-1.040 /-0.868$ & & & -0.632 & -0.328 \\
\hline $3 \mathrm{H}-5$ & $22-24$ & 18.42 & 207.169 & $b_{2.570 / 3.125}$ & $b-0.720 /-0.686$ & ${ }^{a} 1.258$ & ${ }^{a}-0.126$ & -0.838 & 0.368 \\
\hline $3 \mathrm{H}-5$ & $42-44$ & 18.62 & 209.028 & $b_{2.300 / 2.864}$ & $\mathrm{~b}-0.810 /-0.561$ & $a_{1.495}$ & ${ }^{\mathrm{a}} 0.066$ & -0.799 & 0.302 \\
\hline $3 \mathrm{H}-5$ & $62-64$ & 18.82 & 210.887 & $b_{2.230 / 2.734}$ & b $-0.820 /-0.779$ & ${ }^{a} a_{1.366}$ & ${ }^{a} 0.646$ & -0.696 & 0.242 \\
\hline $3 \mathrm{H}-5$ & $82-84$ & 19.02 & 212.746 & 2.193 & -0.805 & ${ }^{a} 1.955$ & ${ }^{\mathrm{a}} 0.217$ & -1.052 & -0.044 \\
\hline $3 \mathrm{H}-5$ & $102-104$ & 19.22 & 214.606 & $b_{2.430 / 2.492}$ & ${ }^{b}-0.920 /-0.918$ & ${ }^{a} 2.030$ & ${ }^{\mathrm{a}} 0.050$ & -1.207 & -0.020 \\
\hline $3 \mathrm{H}-5$ & $122-124$ & 19.42 & 216.465 & 2.239 & -0.704 & 1.530 & 0.149 & -0.869 & 0.161 \\
\hline $3 \mathrm{H}-5$ & $142-144$ & 19.62 & 218.324 & $b_{2.420 / 2.595}$ & ${ }^{b}-0.940 /-0.857$ & a 2.304 & ${ }^{\mathrm{a}} 0.539$ & -1.168 & 0.155 \\
\hline $3 \mathrm{H}-6$ & $12-14$ & 19.82 & 220.183 & 2.390 & -0.850 & 1.688 & 0.099 & -0.816 & 0.173 \\
\hline $3 \mathrm{H}-6$ & $32-34$ & 20.02 & 222.042 & 1.700 & -0.600 & $\mathrm{a}_{1.537}$ & ${ }^{a}-0.048$ & -1.397 & 0.482 \\
\hline $3 \mathrm{H}-6$ & $52-54$ & 20.22 & 223.901 & 2.020 & -0.600 & & & -1.119 & 0.722 \\
\hline $3 \mathrm{H}-6$ & $72-74$ & 20.42 & 225.761 & 2.430 & -0.450 & $a_{2.535}$ & ${ }^{a} 0.711$ & -1.871 & 0.659 \\
\hline $3 \mathrm{H}-6$ & $92-94$ & 20.62 & 227.620 & $\mathrm{~b}_{2.340 / 2.838}$ & b $-0.540 /-0.493$ & & & -1.570 & 0.540 \\
\hline $3 \mathrm{H}-6$ & $112-114$ & 20.82 & 229.479 & 2.110 & -0.550 & 1.190 & ${ }^{a}-0.110$ & -1.059 & 0.332 \\
\hline $3 \mathrm{H}-6$ & $132-134$ & 21.02 & 231.338 & 2.000 & -0.420 & $a_{2.838}$ & ${ }^{\mathrm{a}} 0.669$ & -1.359 & 0.360 \\
\hline $3 \mathrm{H}-7$ & $2-4$ & 21.22 & 233.197 & 2.120 & -0.240 & ${ }^{\mathrm{a}} 2.056$ & ${ }^{\mathrm{a}} 0.315$ & -0.939 & 0.318 \\
\hline $3 \mathrm{H}-7$ & $22-24$ & 21.42 & 235.056 & 2.250 & -0.630 & $a_{1.924}$ & ${ }^{a} 0.174$ & -0.974 & 0.288 \\
\hline $3 \mathrm{H}-7$ & $42-44$ & 21.62 & 236.915 & 2.180 & -0.580 & ${ }^{a} 1.892$ & ${ }^{\mathrm{a}} 0.127$ & -1.225 & 0.433 \\
\hline $3 \mathrm{H}-7$ & $62-64$ & 21.80 & 238.589 & 2.260 & -0.420 & ${ }^{a} 1.854$ & ${ }^{\mathrm{a}} 0.410$ & -1.219 & 0.659 \\
\hline $4 \mathrm{H}-1$ & $10-12$ & 21.82 & 238.775 & 2.510 & -0.500 & 1.972 & 0.226 & -0.898 & 0.469 \\
\hline $4 \mathrm{H}-1$ & $22-24$ & 21.92 & 239.704 & 2.390 & -0.710 & $a_{1.310}$ & ${ }^{\mathrm{a}} 0.150$ & -1.135 & 0.361 \\
\hline $4 \mathrm{H}-1$ & $42-44$ & 22.12 & 241.563 & 2.530 & -0.600 & $\mathrm{a}_{1.380}$ & ${ }^{\mathrm{a}} 0.070$ & -0.939 & 0.130 \\
\hline $4 \mathrm{H}-1$ & $62-64$ & 22.32 & 243.423 & 2.670 & -0.630 & ${ }^{a} 1.470$ & ${ }^{\mathrm{a}} 0.110$ & -1.112 & 0.075 \\
\hline $4 \mathrm{H}-1$ & $82-84$ & 22.52 & 245.282 & 2.550 & -0.790 & ${ }^{a} 2.162$ & ${ }^{\mathrm{a}} 0.407$ & -1.013 & 0.575 \\
\hline $4 \mathrm{H}-1$ & $102-104$ & 22.72 & 247.141 & 2.800 & -0.890 & ${ }^{\mathrm{a}} 1.870$ & ${ }^{\mathrm{a}} 0.163$ & -0.564 & 0.208 \\
\hline $4 \mathrm{H}-1$ & $122-124$ & 22.92 & 249.000 & 2.900 & -0.850 & ${ }^{a} 1.977$ & ${ }^{\mathrm{a}} 0.312$ & -0.772 & 0.223 \\
\hline $4 \mathrm{H}-1$ & $142-144$ & 23.12 & 254.429 & 2.780 & -0.870 & ${ }^{a_{1}} .570 / 1.482$ & ${ }^{\mathrm{a}} 0.010 / 0.081$ & -0.899 & 0.112 \\
\hline $4 \mathrm{H}-2$ & $12-14$ & 23.32 & 259.857 & 2.470 & -0.780 & ${ }^{a} 1.550$ & ${ }^{a}-0.040$ & & \\
\hline $4 \mathrm{H}-2$ & $32-34$ & 23.52 & 265.286 & 2.710 & -0.690 & ${ }^{\mathrm{a}} 1.609$ & ${ }^{\mathrm{a}} 0.159$ & -0.763 & 0.185 \\
\hline $4 \mathrm{H}-2$ & $52-54$ & 23.72 & 270.714 & 2.480 & -0.600 & ${ }^{a_{1.580 / 1.293}}$ & ${ }^{a} 0.000 /-0.024$ & -0.752 & -0.152 \\
\hline $4 \mathrm{H}-2$ & $72-74$ & 23.92 & 276.143 & 2.340 & -1.130 & & & -0.816 & -0.143 \\
\hline $4 \mathrm{H}-2$ & $92-94$ & 24.12 & 281.571 & 2.240 & -1.340 & $\mathrm{a}_{2.241}$ & ${ }^{a} 0.182$ & -0.944 & -0.193 \\
\hline $4 \mathrm{H}-2$ & $112-114$ & 24.32 & 287.000 & 1.920 & -1.260 & ${ }^{a} 1.648$ & ${ }^{\mathrm{a}} 0.131$ & -0.711 & -0.129 \\
\hline $4 \mathrm{H}-2$ & $132-134$ & 24.52 & 289.200 & 2.330 & -0.960 & $\mathrm{~b}_{1.880 / 1.816}$ & ${ }^{b} 0.120 /-0.040$ & -0.756 & 0.171 \\
\hline $4 \mathrm{H}-3$ & $2-4$ & 24.72 & 291.400 & 2.170 & -0.740 & ${ }^{a} 2.001$ & ${ }^{\mathrm{a}} 0.141$ & -0.316 & 0.205 \\
\hline $4 \mathrm{H}-3$ & $22-24$ & 24.92 & 293.600 & 2.400 & -0.560 & 1.940 & 0.360 & -0.461 & 0.246 \\
\hline $4 \mathrm{H}-3$ & $42-44$ & 25.12 & 295.800 & 2.480 & -0.500 & 1.860 & 0.400 & -0.657 & 0.156 \\
\hline $4 \mathrm{H}-3$ & $62-64$ & 25.32 & 298.000 & 2.590 & -0.440 & 2.040 & 0.280 & -0.852 & 0.189 \\
\hline $4 \mathrm{H}-3$ & $82-84$ & 25.52 & 300.200 & 2.610 & -0.510 & 2.020 & 0.170 & -0.970 & 0.340 \\
\hline $4 \mathrm{H}-3$ & $102-104$ & 25.72 & 302.400 & 2.500 & -0.610 & $a_{2.070}$ & ${ }^{\mathrm{a}} 0.140$ & -0.779 & 0.347 \\
\hline $4 \mathrm{H}-3$ & $122-124$ & 25.92 & 304.600 & & & 2.090 & 0.060 & -0.612 & 0.450 \\
\hline $4 \mathrm{H}-3$ & $142-144$ & 26.12 & 306.800 & & & 1.430 & 0.000 & -1.782 & 0.231 \\
\hline $4 \mathrm{H}-4$ & $12-14$ & 26.32 & 309.000 & 2.330 & -0.540 & 1.580 & 0.070 & -1.265 & 0.507 \\
\hline $4 \mathrm{H}-4$ & $32-34$ & 26.52 & 311.200 & 2.220 & -0.440 & 1.680 & 0.210 & -1.154 & 0.537 \\
\hline $4 \mathrm{H}-4$ & $52-54$ & 26.72 & 313.400 & 2.070 & -0.690 & 1.620 & 0.040 & -1.163 & 0.495 \\
\hline $4 \mathrm{H}-4$ & $72-74$ & 26.92 & 315.600 & 2.160 & -0.470 & 1.600 & 0.110 & -1.063 & 0.592 \\
\hline $4 \mathrm{H}-4$ & $92-94$ & 27.12 & 317.800 & 2.210 & -0.280 & 1.750 & 0.180 & -1.390 & 0.604 \\
\hline $4 \mathrm{H}-4$ & $112-114$ & 27.32 & 320.000 & 2.050 & -0.550 & 1.570 & 0.120 & -1.182 & 0.478 \\
\hline $4 \mathrm{H}-4$ & $132-134$ & 27.52 & 322.200 & 1.890 & -0.450 & 1.370 & -0.090 & -0.921 & 0.804 \\
\hline $4 \mathrm{H}-5$ & 2-4 & 27.72 & 324.400 & 2.030 & -0.460 & ${ }^{a} 1.750$ & ${ }^{a}-0.170$ & -1.047 & 0.582 \\
\hline $4 \mathrm{H}-5$ & $22-24$ & 27.92 & 326.600 & & & 1.234 & -0.150 & -1.406 & 0.574 \\
\hline $4 \mathrm{H}-5$ & $42-44$ & 28.12 & 328.800 & 1.940 & -0.340 & ${ }^{a} 1.610$ & ${ }^{a}-0.060$ & -1.396 & 0.377 \\
\hline $4 \mathrm{H}-5$ & $62-64$ & 28.32 & 331.000 & 1.620 & -0.230 & 1.000 & -0.480 & -1.667 & 0.171 \\
\hline $4 \mathrm{H}-5$ & $82-84$ & 28.52 & 332.667 & 1.760 & -0.530 & 1.260 & -0.360 & -1.120 & 0.151 \\
\hline $4 \mathrm{H}-5$ & $102-104$ & 28.72 & 334.333 & 2.390 & -0.580 & $a_{2.200}$ & ${ }^{a}-0.150$ & -0.771 & 0.080 \\
\hline $4 \mathrm{H}-5$ & $122-124$ & 28.92 & 336.000 & 2.090 & -0.340 & 1.450 & -0.160 & -0.617 & -0.038 \\
\hline $4 \mathrm{H}-5$ & $142-144$ & 29.12 & 337.667 & 2.060 & -0.810 & 1.580 & 0.180 & -0.272 & -0.026 \\
\hline $4 \mathrm{H}-6$ & $12-14$ & 29.32 & 339.333 & 2.640 & -0.940 & ${ }^{a} 1.540$ & ${ }^{a} 0.240$ & -0.459 & -0.207 \\
\hline $4 \mathrm{H}-6$ & $32-34$ & 29.52 & 341.000 & & & 2.040 & -0.080 & -0.188 & -0.025 \\
\hline $4 \mathrm{H}-6$ & $52-54$ & 29.72 & 342.667 & 2.110 & -1.520 & 1.470 & -0.050 & -0.266 & -0.122 \\
\hline
\end{tabular}


Appendix A (continued).

\begin{tabular}{|c|c|c|c|c|c|c|c|c|c|}
\hline \multirow[b]{2}{*}{$\begin{array}{l}\text { Core, } \\
\text { section }\end{array}$} & \multirow{2}{*}{$\begin{array}{c}\text { Depth } \\
\text { in section } \\
(\mathrm{cm})\end{array}$} & \multirow{2}{*}{$\begin{array}{l}\text { Sub-bottom } \\
\text { depth } \\
\text { (m) }\end{array}$} & \multirow[b]{2}{*}{$\begin{array}{c}\text { Age } \\
\text { (1000 yrB.P.) }\end{array}$} & \multicolumn{2}{|c|}{ Uvigerina spp. } & \multicolumn{2}{|c|}{ Cibicidoides spp. } & \multicolumn{2}{|c|}{ G. ruber (white) } \\
\hline & & & & $\begin{array}{c}\delta^{18} \mathrm{O} \\
(\% 0 \mathrm{PDB})\end{array}$ & $\begin{array}{c}\delta^{13} \mathrm{C} \\
(\%, \mathrm{PDB})\end{array}$ & $\begin{array}{c}\delta^{18} \mathrm{O} \\
\left(\%_{0} \mathrm{PDB}\right)\end{array}$ & $\begin{array}{c}\delta^{13} \mathrm{C} \\
(\% \circ \mathrm{PDB})\end{array}$ & $\begin{array}{c}\delta^{18} \mathrm{O} \\
\left(\%_{0} \mathrm{PDB}\right)\end{array}$ & $\begin{array}{c}\delta^{13} \mathrm{C} \\
\left(\%_{0} \mathrm{PDB}\right)\end{array}$ \\
\hline $4 \mathrm{H}-6$ & $72-74$ & 29.92 & 344.333 & 2.770 & -0.680 & $a_{2.480}$ & $\mathrm{a}-0.290$ & -0.270 & -0.058 \\
\hline $4 \mathrm{H}-6$ & $92-94$ & 30.12 & 346.000 & 2.970 & -0.800 & $a_{2.550}$ & $\mathrm{a}-0.320$ & -0.477 & 0.083 \\
\hline $4 \mathrm{H}-6$ & $132-134$ & 30.52 & 349.333 & 2.810 & -0.860 & 2.060 & -0.070 & -0.408 & 0.111 \\
\hline $4 \mathrm{H}-7$ & $18-20$ & 30.88 & 352.333 & & & 2.430 & -0.330 & -0.433 & 0.006 \\
\hline $4 \mathrm{H}-7$ & $38-40$ & 31.08 & 354.000 & & & & & -0.472 & 0.141 \\
\hline $4 \mathrm{H}-7$ & $58-60$ & 31.28 & 355.667 & & & & & -0.495 & -0.089 \\
\hline $4 \mathrm{H}-7$ & $78-80$ & 31.48 & 357.333 & & & & & -1.141 & -0.137 \\
\hline
\end{tabular}

a Value has been rejected (see text).

${ }^{b}$ Mean of replicates has been used.

APPENDIX B

Density and Organic Carbon Data for Hole 724C

\begin{tabular}{|c|c|c|c|c|c|c|c|c|}
\hline $\begin{array}{l}\text { Core, } \\
\text { section }\end{array}$ & $\begin{array}{l}\text { Depth } \\
\text { in section } \\
\text { (cm) }\end{array}$ & $\begin{array}{l}\text { Depth } \\
\text { in hole } \\
\text { (m) }\end{array}$ & $\begin{array}{l}\text { Age } \\
\text { (k.y.) }\end{array}$ & $\begin{array}{l}C_{\text {org }} \\
(w t \%)\end{array}$ & $\begin{array}{l}\text { Wet bulk } \\
\text { density } \\
\left(\mathrm{g} \mathrm{cm}^{-3}\right)^{\mathrm{a}}\end{array}$ & $\begin{array}{c}\text { Dry bulk } \\
\text { density } \\
\left(\mathrm{g} \mathrm{cm}^{-3}\right)^{\mathrm{b}}\end{array}$ & $\begin{array}{c}\text { Sedimentation } \\
\text { rates } \\
\left(\mathrm{cm} \mathrm{k.y.}{ }^{-1}\right)^{\mathrm{c}}\end{array}$ & $\begin{array}{c}C_{\text {org }} \\
\left(\mathrm{g} \mathrm{cm}^{-2} \text { k.y. }{ }^{-1}\right)\end{array}$ \\
\hline $1 \mathrm{H}-1$ & $25-27$ & 0.25 & 6.33 & 1.753 & 1.473 & 0.643 & 15.00 & 16.908 \\
\hline $1 \mathrm{H}-1$ & $45-47$ & 0.45 & 7.67 & 1.545 & 1.561 & 0.783 & 15.00 & 18.146 \\
\hline $1 \mathrm{H}-1$ & $65-67$ & 0.65 & 9.00 & 0.894 & 1.680 & 0.970 & 15.00 & 13.008 \\
\hline $1 \mathrm{H}-1$ & $85-87$ & 0.85 & 10.33 & 0.909 & 1.706 & 1.013 & 15.00 & 13.812 \\
\hline $1 \mathrm{H}-1$ & $105-107$ & 1.05 & 11.67 & 1.151 & 1.737 & 1.061 & 15.00 & 18.318 \\
\hline $1 \mathrm{H}-1$ & $125-127$ & 1.25 & 13.00 & 0.436 & 1.866 & 1.265 & 15.00 & 8.273 \\
\hline $1 \mathrm{H}-1$ & $145-147$ & 1.45 & 14.33 & 0.575 & 1.905 & 1.327 & 15.00 & 11.445 \\
\hline $1 \mathrm{H}-2$ & $15-17$ & 1.65 & 15.67 & 0.527 & 1.888 & 1.301 & 15.00 & 10.284 \\
\hline $1 \mathrm{H}-2$ & $35-37$ & 1.85 & 17.00 & 0.683 & 1.849 & 1.238 & 15.00 & 12.683 \\
\hline $1 \mathrm{H}-2$ & $55-57$ & 2.05 & 18.33 & 1.234 & 1.744 & 1.072 & 15.00 & 19.843 \\
\hline $1 \mathrm{H}-2$ & $75-77$ & 2.25 & 19.67 & 1.033 & 1.725 & 1.043 & 15.00 & 16.161 \\
\hline $1 \mathrm{H}-2$ & $95-97$ & 2.45 & 21.00 & 1.180 & 1.749 & 1.081 & 15.00 & 19.134 \\
\hline $2 \mathrm{H}-1$ & $10-12$ & 2.90 & 24.08 & 0.781 & 1.715 & 1.026 & 15.00 & 12.020 \\
\hline $2 \mathrm{H}-1$ & $25-27$ & 3.05 & 25.49 & 0.768 & 1.825 & 1.200 & 10.09 & 9.299 \\
\hline $2 \mathrm{H}-1$ & $45-47$ & 3.25 & 27.48 & 1.193 & 1.775 & 1.121 & 10.09 & 13.494 \\
\hline $2 \mathrm{H}-1$ & $65-67$ & 3.45 & 29.47 & 1.602 & 1.770 & 1.113 & 10.09 & 17.991 \\
\hline $2 \mathrm{H}-1$ & $85-87$ & 3.65 & 31.46 & 0.666 & 1.805 & 1.169 & 10.09 & 7.856 \\
\hline $2 \mathrm{H}-1$ & $105-107$ & 3.85 & 33.45 & 1.977 & 1.747 & 1.077 & 10.09 & 21.484 \\
\hline $2 \mathrm{H}-1$ & $125-127$ & 4.05 & 35.43 & 3.849 & 1.698 & 0.999 & 10.09 & 38.798 \\
\hline $2 \mathrm{H}-1$ & $145-147$ & 4.25 & 37.42 & 0.829 & 1.796 & 1.155 & 10.09 & 9.661 \\
\hline $2 \mathrm{H}-2$ & $15-17$ & 4.45 & 39.41 & 1.031 & 1.815 & 1.185 & 10.09 & 12.327 \\
\hline $2 \mathrm{H}-2$ & $35-37$ & 4.65 & 41.40 & 1.670 & 1.763 & 1.102 & 10.09 & 18.569 \\
\hline $2 \mathrm{H}-2$ & $55-57$ & 4.85 & 43.39 & 1.653 & 1.749 & 1.080 & 10.09 & 18.013 \\
\hline $2 \mathrm{H}-2$ & $75-77$ & 5.05 & 45.38 & 1.721 & 1.751 & 1.083 & 10.09 & 18.806 \\
\hline $2 \mathrm{H}-2$ & 95-97 & 5.25 & 47.37 & 1.095 & 1.792 & 1.149 & 10.09 & 12.695 \\
\hline $2 \mathrm{H}-2$ & $115-117$ & 5.45 & 49.36 & 1.437 & 1.768 & 1.110 & 10.09 & 16.094 \\
\hline $2 \mathrm{H}-2$ & $135-137$ & 5.65 & 51.34 & 1.176 & 1.796 & 1.155 & 10.09 & 13.705 \\
\hline $2 \mathrm{H}-3$ & $5-7$ & 5.85 & 53.33 & 0.538 & 1.816 & 1.186 & 10.09 & 6.438 \\
\hline $2 \mathrm{H}-3$ & $25-27$ & 6.05 & 55.32 & 0.723 & 1.831 & 1.210 & 10.09 & 8.827 \\
\hline $2 \mathrm{H}-3$ & $45-47$ & 6.25 & 57.31 & 0.654 & 1.829 & 1.207 & 10.09 & 7.965 \\
\hline $2 \mathrm{H}-3$ & $65-67$ & 6.45 & 59.30 & 0.511 & 1.830 & 1.208 & 10.09 & 6.228 \\
\hline $2 \mathrm{H}-3$ & $85-87$ & 6.65 & 61.30 & 0.776 & 1.835 & 1.217 & 10.00 & 9.444 \\
\hline $2 \mathrm{H}-3$ & $105-107$ & 6.85 & 63.30 & 0.664 & 1.862 & 1.259 & 10.00 & 8.360 \\
\hline $2 \mathrm{H}-3$ & $125-127$ & 7.05 & 65.30 & 0.857 & 1.869 & 1.271 & 10.00 & 10.892 \\
\hline $2 \mathrm{H}-3$ & $145-147$ & 7.25 & 67.30 & 1.588 & 1.822 & 1.196 & 10.00 & 18.992 \\
\hline $2 \mathrm{H}-4$ & $15-17$ & 7.45 & 69.30 & 1.107 & 1.781 & 1.131 & 10.00 & 12.520 \\
\hline $2 \mathrm{H}-4$ & $35-37$ & 7.65 & 71.84 & 1.553 & 1.752 & 1.086 & 10.00 & 16.866 \\
\hline $2 \mathrm{H}-4$ & $55-57$ & 7.85 & 77.41 & 1.807 & 1.724 & 1.041 & 3.53 & 6.640 \\
\hline $2 \mathrm{H}-4$ & $75-77$ & 8.05 & 82.98 & 1.140 & 1.774 & 1.120 & 3.53 & 4.507 \\
\hline $2 \mathrm{H}-4$ & $95-97$ & 8.25 & 88.55 & 1.269 & 1.779 & 1.128 & 3.53 & 5.053 \\
\hline $2 \mathrm{H}-4$ & $115-117$ & 8.45 & 94.12 & 1.642 & 1.756 & 1.091 & 3.53 & 6.324 \\
\hline $2 \mathrm{H}-4$ & $135-137$ & 8.65 & 99.69 & 1.197 & 1.744 & 1.072 & 3.53 & 4.530 \\
\hline $2 \mathrm{H}-5$ & $5-7$ & 8.85 & 105.27 & 1.073 & 1.722 & 1.038 & 3.53 & 3.932 \\
\hline $2 \mathrm{H}-5$ & $25-27$ & 9.05 & 110.90 & 1.326 & 1.754 & 1.089 & 3.53 & 5.097 \\
\hline $2 \mathrm{H}-5$ & $45-47$ & 9.25 & 116.90 & 1.190 & 1.774 & 1.119 & 3.53 & 4.701 \\
\hline $2 \mathrm{H}-5$ & $65-67$ & 9.45 & 122.18 & 0.915 & 1.830 & 1.208 & 3.53 & 3.902 \\
\hline $2 \mathrm{H}-5$ & $85-87$ & 9.65 & 123.36 & 0.682 & 1.860 & 1.256 & 11.72 & 10.039 \\
\hline $2 \mathrm{H}-5$ & $105-107$ & 9.85 & 124.54 & 0.484 & 1.866 & 1.266 & 11.72 & 7.181 \\
\hline $2 \mathrm{H}-5$ & $125-127$ & 10.05 & 125.72 & 0.539 & 1.929 & 1.365 & 11.72 & 8.623 \\
\hline $2 \mathrm{H}-5$ & $145-147$ & 10.25 & 126.90 & 0.440 & 1.932 & 1.371 & 11.72 & 7.070 \\
\hline $2 \mathrm{H}-6$ & $15-17$ & 10.45 & 128.09 & 0.684 & 1.891 & 1.305 & 11.72 & 10.462 \\
\hline $2 \mathrm{H}-6$ & $35-37$ & 10.65 & 129.27 & 0.591 & 1.886 & 1.297 & 11.72 & 8.984 \\
\hline $2 \mathrm{H}-6$ & $55-57$ & 10.85 & 130.45 & 0.652 & 1.913 & 1.340 & 11.72 & 10.240 \\
\hline $2 \mathrm{H}-6$ & $75-77$ & 11.05 & 131.63 & 0.793 & 1.912 & 1.338 & 11.72 & 12.435 \\
\hline $2 \mathrm{H}-6$ & 95-97 & 11.25 & 132.81 & 0.642 & 1.925 & 1.360 & 11.72 & 10.233 \\
\hline $2 \mathrm{H}-6$ & $115-117$ & 11.45 & 134.00 & 0.866 & 1.898 & 1.316 & 11.72 & 13.357 \\
\hline
\end{tabular}


Appendix B (continued).

\begin{tabular}{|c|c|c|c|c|c|c|c|c|}
\hline $\begin{array}{l}\text { Core, } \\
\text { section }\end{array}$ & $\begin{array}{c}\text { Depth } \\
\text { in section } \\
\text { (cm) }\end{array}$ & $\begin{array}{l}\text { Depth } \\
\text { in hole } \\
\text { (m) }\end{array}$ & $\begin{array}{l}\text { Age } \\
\text { (k.y.) }\end{array}$ & $\begin{array}{l}\mathrm{C}_{\mathrm{org}} \\
(\mathrm{wt} \%)\end{array}$ & $\begin{array}{l}\text { Wet bulk } \\
\text { density } \\
\left(\mathrm{g} \mathrm{cm}^{-3}\right)^{\mathrm{a}}\end{array}$ & $\begin{array}{c}\text { Dry bulk } \\
\text { density } \\
\left(\mathrm{g} \mathrm{cm}^{-3}\right)^{\mathrm{b}}\end{array}$ & $\begin{array}{c}\text { Sedimentation } \\
\text { rates } \\
(\mathrm{cm} \mathrm{k.y.}-1)^{\mathrm{c}}\end{array}$ & $\begin{array}{c}\mathrm{C}_{\text {org }} \\
\left(\mathrm{g} \mathrm{cm}^{-2} \text { k.y. }{ }^{-1}\right)\end{array}$ \\
\hline $2 \mathrm{H}-6$ & $135-137$ & 11.65 & 135.42 & 1.416 & 1.835 & 1.217 & 11.72 & 20.197 \\
\hline $2 \mathrm{H}-7$ & 5-7 & 11.85 & 138.18 & 0.697 & 1.849 & 1.238 & 11.72 & 10.113 \\
\hline $2 \mathrm{H}-7$ & $25-27$ & 12.05 & 140.95 & 0.877 & 1.701 & $1.004^{\mathrm{d}}(1.238)$ & 11.72 & $10.320^{d}(12.725)$ \\
\hline $2 \mathrm{H}-7$ & $45-47$ & 12.25 & 143.72 & 1.252 & 1.454 & $0.612^{d}(1.238)$ & 11.72 & $8.980 \mathrm{~d}(18.166)$ \\
\hline $2 \mathrm{H}-7$ & $60-62$ & 12.40 & 145.80 & 0.897 & 1.454 & $0.612^{d}(1.238)$ & 11.72 & $6.434^{d}(13.015)$ \\
\hline $3 \mathrm{H}-1$ & $25-27$ & 12.45 & 146.49 & 1.188 & 1.640 & $0.908^{d}(1.238)$ & 11.72 & $12.642^{\mathrm{d}}(17.237)$ \\
\hline $3 \mathrm{H}-1$ & $45-47$ & 12.65 & 149.26 & 1.074 & 1.825 & $1.200^{\mathrm{d}}(1.238)$ & 11.72 & $15.105^{d}(15.583)$ \\
\hline $3 \mathrm{H}-1$ & $65-67$ & 12.85 & 152.03 & 0.908 & 1.886 & 1.297 & 11.72 & 13.802 \\
\hline $3 \mathrm{H}-1$ & $85-87$ & 13.05 & 154.80 & 0.810 & 1.920 & 1.352 & 11.72 & 12.835 \\
\hline $3 \mathrm{H}-1$ & $105-107$ & 13.25 & 157.57 & 0.873 & 1.896 & 1.313 & 11.72 & 13.434 \\
\hline $3 \mathrm{H}-1$ & $125-127$ & 13.45 & 160.34 & 0.713 & 1.934 & 1.373 & 11.72 & 11.473 \\
\hline $3 \mathrm{H}-1$ & $145-147$ & 13.65 & 163.11 & 0.681 & 1.955 & 1.406 & 11.72 & 11.222 \\
\hline $3 \mathrm{H}-2$ & $15-17$ & 13.85 & 165.88 & 0.743 & 1.940 & 1.383 & 11.72 & 12.043 \\
\hline $3 \mathrm{H}-2$ & $35-37$ & 14.05 & 168.65 & 0.502 & 1.920 & 1.351 & 11.72 & 7.949 \\
\hline $3 \mathrm{H}-2$ & $55-57$ & 14.25 & 171.23 & 0.481 & 1.956 & 1.409 & 11.72 & 7.943 \\
\hline $3 \mathrm{H}-2$ & $75-77$ & 14.45 & 172.73 & 0.439 & 1.970 & 1.431 & 11.72 & 7.363 \\
\hline $3 \mathrm{H}-2$ & $95-97$ & 14.65 & 174.23 & 0.491 & 1.976 & 1.440 & 11.72 & 8.287 \\
\hline $3 \mathrm{H}-2$ & $115-117$ & 14.85 & 175.73 & 0.501 & 1.992 & 1.465 & 11.72 & 8.602 \\
\hline $3 \mathrm{H}-2$ & $135-137$ & 15.05 & 177.23 & 0.645 & 1.977 & 1.441 & 11.72 & 10.893 \\
\hline $3 \mathrm{H}-3$ & $5-7$ & 15.25 & 178.73 & 0.821 & 1.947 & 1.394 & 11.72 & 13.413 \\
\hline $3 \mathrm{H}-3$ & $25-27$ & 15.45 & 180.23 & 0.951 & 1.902 & 1.322 & 11.72 & 14.735 \\
\hline $3 \mathrm{H}-3$ & $45-47$ & 15.65 & 181.73 & 1.305 & 1.878 & 1.284 & 11.72 & 19.638 \\
\hline $3 \mathrm{H}-3$ & $65-67$ & 15.85 & 183.28 & 0.818 & 1.870 & 1.272 & 11.72 & 12.165 \\
\hline $3 \mathrm{H}-3$ & $85-87$ & 16.05 & 185.14 & 1.650 & 1.885 & 1.296 & 11.72 & 25.062 \\
\hline $3 \mathrm{H}-3$ & $105-107$ & 16.25 & 187.00 & 0.734 & 1.825 & 1.201 & 11.72 & 10.332 \\
\hline $3 \mathrm{H}-3$ & $125-127$ & 16.45 & 188.86 & 0.862 & 1.891 & 1.305 & 10.68 & 9.227 \\
\hline $3 \mathrm{H}-3$ & $145-147$ & 16.65 & 190.72 & 0.617 & 1.953 & 1.403 & 10.68 & 9.245 \\
\hline $3 \mathrm{H}-4$ & $15-17$ & 16.85 & 192.58 & 0.749 & 1.953 & 1.404 & 10.68 & 11.231 \\
\hline $3 \mathrm{H}-4$ & $35-37$ & 17.05 & 194.43 & 1.774 & 1.937 & 1.379 & 10.68 & 26.127 \\
\hline $3 \mathrm{H}-4$ & $55-57$ & 17.25 & 196.29 & 0.684 & 1.852 & 1.244 & 10.68 & 9.088 \\
\hline $3 \mathrm{H}-4$ & $75-77$ & 17.45 & 198.15 & 0.699 & 1.901 & 1.322 & 10.68 & 9.869 \\
\hline $3 \mathrm{H}-4$ & $95-97$ & 17.65 & 200.01 & 1.661 & 1.955 & 1.406 & 10.68 & 24.942 \\
\hline $3 \mathrm{H}-4$ & $115-117$ & 17.85 & 201.87 & 0.870 & 1.944 & 1.389 & 10.68 & 12.906 \\
\hline $3 \mathrm{H}-4$ & $135-137$ & 18.05 & 203.73 & 1.232 & 1.870 & 1.271 & 10.68 & 16.724 \\
\hline $3 \mathrm{H}-5$ & $5-7$ & 18.25 & 205.59 & 0.919 & 1.765 & 1.106 & 10.68 & 10.855 \\
\hline $3 \mathrm{H}-5$ & $25-27$ & 18.45 & 207.45 & 1.024 & 1.872 & 1.275 & 10.68 & 13.944 \\
\hline $3 \mathrm{H}-5$ & $4-47$ & 18.65 & 209.31 & 0.972 & 1.903 & 1.325 & 10.68 & 13.755 \\
\hline $3 \mathrm{H}-5$ & $65-67$ & 18.85 & 211.17 & 0.724 & 1.899 & 1.317 & 10.68 & 10.183 \\
\hline $3 \mathrm{H}-5$ & $85-87$ & 19.05 & 213.03 & 0.588 & 1.909 & 1.333 & 10.68 & 8.371 \\
\hline $3 \mathrm{H}-5$ & $105-107$ & 19.25 & 214.89 & 0.856 & 1.897 & 1.316 & 10.68 & 12.031 \\
\hline $3 \mathrm{H}-5$ & $125-127$ & 19.45 & 216.74 & 1.162 & 1.896 & 1.313 & 10.68 & 16.295 \\
\hline $3 \mathrm{H}-5$ & $145-147$ & 19.65 & 218.60 & 1.408 & 1.886 & 1.298 & 10.68 & 19.519 \\
\hline $3 \mathrm{H}-6$ & $15-17$ & 19.85 & 220.46 & 1.535 & 1.821 & 1.194 & 10.68 & 19.574 \\
\hline $3 \mathrm{H}-6$ & $35-37$ & 20.05 & 222.32 & 1.382 & 1.734 & 1.057 & 10.68 & 15.601 \\
\hline $3 \mathrm{H}-6$ & $55-57$ & 20.25 & 224.18 & 1.756 & 1.745 & 1.075 & 10.68 & 20.161 \\
\hline $3 \mathrm{H}-6$ & $75-77$ & 20.45 & 226.04 & 1.451 & 1.747 & 1.076 & 10.68 & 16.674 \\
\hline $3 \mathrm{H}-6$ & $95-97$ & 20.65 & 227.90 & 1.072 & 1.733 & 1.055 & 10.68 & 12.079 \\
\hline $3 \mathrm{H}-6$ & $115-117$ & 20.85 & 229.76 & 0.836 & 1.804 & 1.168 & 10.68 & 10.428 \\
\hline $3 \mathrm{H}-6$ & $135-137$ & 21.05 & 231.62 & 0.743 & 1.856 & 1.249 & 10.68 & 9.911 \\
\hline $3 \mathrm{H}-7$ & $5-7$ & 21.25 & 233.48 & 0.622 & 1.902 & 1.323 & 10.68 & 8.789 \\
\hline $3 \mathrm{H}-7$ & $25-27$ & 21.45 & 235.34 & 1.314 & 1.618 & $0.873^{\mathrm{d}}(1.323)$ & 10.68 & $12.251^{d}(18.566)$ \\
\hline $3 \mathrm{H}-7$ & $45-47$ & 21.65 & 237.19 & 1.330 & 1.463 & $0.628^{\mathrm{d}}(1.323)$ & 10.68 & $8.920^{d}(18.792)$ \\
\hline $3 \mathrm{H}-7$ & $65-67$ & 21.85 & 239.05 & 0.649 & 1.634 & $0.897^{d}(1.323)$ & 10.68 & $6.217^{d}(9.170)$ \\
\hline $4 \mathrm{H}-1$ & $13-15$ & 21.83 & 238.87 & 0.906 & 1.634 & $0.897 \mathrm{~d}(1.323)$ & 10.68 & $8.679^{d}(12.801)$ \\
\hline $4 \mathrm{H}-1$ & $25-27$ & 21.95 & 239.98 & 0.632 & 1.797 & $1.157 \mathrm{~d}(1.323)$ & 10.68 & $7.809^{d}(8.930)$ \\
\hline $4 \mathrm{H}-1$ & $45-47$ & 22.15 & 241.84 & 0.693 & 1.867 & 1.267 & 10.68 & 9.377 \\
\hline $4 \mathrm{H}-1$ & $65-67$ & 22.35 & 243.70 & 1.031 & 1.874 & 1.279 & 10.68 & 14.083 \\
\hline $4 \mathrm{H}-1$ & $85-87$ & 22.55 & 245.56 & 1.532 & 1.870 & 1.271 & 10.68 & 20.796 \\
\hline $4 \mathrm{H}-1$ & $105-107$ & 22.75 & 247.42 & 1.497 & 1.848 & 1.237 & 5.86 & 10.851 \\
\hline $4 \mathrm{H}-1$ & $125-127$ & 22.95 & 249.81 & 1.152 & 1.844 & 1.231 & 5.86 & 8.310 \\
\hline $4 \mathrm{H}-1$ & $145-147$ & 23.15 & 255.24 & 1.171 & 1.867 & 1.267 & 5.86 & 8.694 \\
\hline $4 \mathrm{H}-2$ & $15-17$ & 23.35 & 260.67 & 1.671 & 1.846 & 1.234 & 5.86 & 12.083 \\
\hline $4 \mathrm{H}-2$ & $35-37$ & 23.55 & 266.10 & 0.803 & 1.871 & 1.274 & 5.86 & 5.995 \\
\hline $4 \mathrm{H}-2$ & $55-57$ & 23.75 & 271.53 & 1.268 & 1.885 & 1.296 & 5.86 & 9.630 \\
\hline $4 \mathrm{H}-2$ & $75-77$ & 23.95 & 276.96 & 0.949 & 1.910 & 1.335 & 5.86 & 7.424 \\
\hline $4 \mathrm{H}-2$ & $95-97$ & 24.15 & 282.39 & 0.685 & 1.908 & 1.332 & 5.86 & 5.347 \\
\hline $4 \mathrm{H}-2$ & $115-117$ & 24.35 & 287.33 & 0.564 & 1.905 & 1.327 & 5.86 & 4.386 \\
\hline $4 \mathrm{H}-2$ & $135-137$ & 24.55 & 289.53 & 0.479 & 1.900 & 1.320 & 5.86 & 3.705 \\
\hline $4 \mathrm{H}-3$ & $5-7$ & 24.75 & 291.73 & 0.768 & 1.914 & 1.341 & 5.86 & 6.035 \\
\hline $4 \mathrm{H}-3$ & $25-27$ & 24.95 & 293.93 & 0.410 & 1.916 & 1.344 & 5.86 & 3.229 \\
\hline $4 \mathrm{H}-3$ & $45-47$ & 25.15 & 296.13 & 0.344 & 1.915 & 1.344 & 5.86 & 2.709 \\
\hline $4 \mathrm{H}-3$ & $65-67$ & 25.35 & 298.33 & 0.479 & 1.890 & 1.304 & 5.86 & 3.660 \\
\hline $4 \mathrm{H}-3$ & $85-87$ & 25.85 & 303.83 & 1.013 & 1.860 & 1.256 & 5.86 & 7.456 \\
\hline $4 \mathrm{H}-3$ & $105-107$ & 25.75 & 302.73 & 1.003 & 1.855 & 1.248 & 5.86 & 7.335 \\
\hline $4 \mathrm{H}-3$ & $125-127$ & 25.95 & 304.93 & 1.180 & 1.863 & 1.261 & 5.86 & 8.720 \\
\hline $4 \mathrm{H}-3$ & $145-147$ & 26.15 & 307.13 & 1.230 & 1.875 & 1.281 & 9.44 & 14.874 \\
\hline $4 \mathrm{H}-4$ & $15-17$ & 26.35 & 309.33 & 1.286 & 1.875 & ${ }^{\mathrm{e}} 1.281$ & 9.44 & 15.551 \\
\hline
\end{tabular}


Appendix B (continued).

\begin{tabular}{|c|c|c|c|c|c|c|c|c|}
\hline $\begin{array}{l}\text { Core, } \\
\text { section }\end{array}$ & $\begin{array}{l}\text { Depth } \\
\text { in section } \\
(\mathrm{cm})\end{array}$ & $\begin{array}{l}\text { Depth } \\
\text { in hole } \\
(\mathrm{m})\end{array}$ & $\begin{array}{l}\text { Age } \\
\text { (k.y.) }\end{array}$ & $\begin{array}{l}\mathrm{C}_{\text {org }} \\
\text { (wt\%) }\end{array}$ & $\begin{array}{l}\text { Wet bulk } \\
\text { density } \\
\left(\mathrm{g} \mathrm{cm}^{-3}\right)^{\mathrm{a}}\end{array}$ & $\begin{array}{l}\text { Dry bulk } \\
\text { density } \\
\left(\mathrm{g} \mathrm{cm}^{-3}\right)^{\mathrm{b}}\end{array}$ & $\begin{array}{c}\text { Sedimentation } \\
\text { rates } \\
\left.(\mathrm{cm} \mathrm{k.y.})^{-1}\right)^{\mathrm{c}}\end{array}$ & $\left.\frac{C_{\text {org }}}{\left(\mathrm{g} \mathrm{cm}^{-2} \text { k.y. }\right.}{ }^{-1}\right)$ \\
\hline $4 \mathrm{H}-4$ & $35-37$ & 26.55 & 311.53 & 1.239 & 1.875 & $e_{1.281}$ & 9.44 & 14.983 \\
\hline $4 \mathrm{H}-4$ & $55-57$ & 26.75 & 313.73 & 1.049 & 1.875 & $e_{1.281}$ & 9.44 & 12.685 \\
\hline $4 \mathrm{H}-4$ & $75-77$ & 26.95 & 315.93 & 1.106 & 1.875 & ${ }^{\mathrm{e}} 1.281$ & 9.44 & 13.374 \\
\hline $4 \mathrm{H}-4$ & $95-97$ & 27.15 & 318.13 & 1.116 & 1.875 & $e^{e} 1.281$ & 9.44 & 13.495 \\
\hline $4 \mathrm{H}-4$ & $115-117$ & 27.35 & 320.33 & 1.592 & 1.875 & $e_{1.281}$ & 9.44 & 19.251 \\
\hline $4 \mathrm{H}-4$ & $135-137$ & 27.55 & 322.53 & 1.641 & 1.791 & 1.147 & 9.44 & 17.768 \\
\hline $4 \mathrm{H}-5$ & 5-7 & 27.75 & 324.73 & 1.932 & 1.798 & 1.157 & 9.44 & 21.101 \\
\hline $4 \mathrm{H}-5$ & $25-27$ & 27.95 & 326.93 & 1.127 & 1.821 & 1.195 & 9.44 & 12.713 \\
\hline $4 \mathrm{H}-5$ & $45-47$ & 28.15 & 329.13 & 0.785 & 1.880 & 1.288 & 9.44 & 9.545 \\
\hline $4 \mathrm{H}-5$ & $65-67$ & 28.35 & 331.25 & 0.750 & 1.904 & 1.326 & 9.44 & 9.388 \\
\hline $4 \mathrm{H}-5$ & $85-87$ & 28.55 & 332.92 & 0.423 & 1.920 & 1.351 & 9.44 & 5.395 \\
\hline $4 \mathrm{H}-5$ & $105-107$ & 28.75 & 334.58 & 0.784 & 1.932 & 1.370 & 9.44 & 10.139 \\
\hline $4 \mathrm{H}-5$ & $125-127$ & 28.95 & 336.25 & 0.322 & 1.950 & 1.399 & 9.44 & 4.253 \\
\hline $4 \mathrm{H}-5$ & $145-147$ & 29.15 & 337.92 & 0.375 & 1.981 & 1.447 & 9.44 & 5.122 \\
\hline $4 \mathrm{H}-6$ & $15-17$ & 29.35 & 339.58 & 0.344 & 1.975 & 1.439 & 9.44 & 4.673 \\
\hline $4 \mathrm{H}-6$ & $35-37$ & 29.55 & 341.25 & 0.336 & 1.976 & 1.441 & 12.00 & 5.810 \\
\hline $4 \mathrm{H}-6$ & $55-57$ & 29.75 & 342.92 & 0.411 & 1.986 & 1.455 & 12.00 & 7.178 \\
\hline $4 \mathrm{H}-6$ & $75-77$ & 29.95 & 344.58 & 0.659 & 1.986 & 1.455 & 12.00 & 11.510 \\
\hline $4 \mathrm{H}-6$ & $95-97$ & 30.15 & 346.25 & 0.869 & 1.974 & 1.437 & 12.00 & 14.985 \\
\hline $4 \mathrm{H}-6$ & $115-117$ & 30.35 & 347.92 & 0.906 & 1.945 & 1.390 & 12.00 & 15.112 \\
\hline $4 \mathrm{H}-6$ & $135-137$ & 30.55 & 349.58 & 0.834 & 1.946 & 1.393 & 12.00 & 13.941 \\
\hline $4 \mathrm{H}-7$ & $15-17$ & 30.85 & 352.08 & 0.915 & 1.940 & 1.382 & 12.00 & 15.174 \\
\hline $4 \mathrm{H}-7$ & $35-37$ & 31.05 & 353.75 & 0.677 & 1.922 & 1.354 & 12.00 & 11.000 \\
\hline $4 \mathrm{H}-7$ & $55-57$ & 31.25 & 355.42 & 0.833 & 1.911 & 1.336 & 12.00 & 13.355 \\
\hline
\end{tabular}

a GRAPE data.

${ }^{b}$ GRAPE data corrected to dry bulk density measured.

c Mean values calculated by linear interpolation between oxygen isotope boundaries.

Measured wet bulk density decreases sharply at core break; constant value from above the break has been used to calculate organic carbon accumulation.

e No GRAPE density data were available for Section $728 \mathrm{C}-4 \mathrm{H}-4$; here the value from the bottom of Section $728 \mathrm{C}-4 \mathrm{H}-3$ has been used to calculate organic carbon accumulation. 